Article

\title{
The Budesonide-Hydroxypropyl- $\beta$-Cyclodextrin Complex Attenuates ROS Generation, IL-8 Release and Cell Death Induced by Oxidant and Inflammatory Stress. Study on A549 and A-THP-1 Cells
}

\author{
Jules César Bayiha ${ }^{1}$, Brigitte Evrard ${ }^{2}$, Didier Cataldo ${ }^{3}$, Pascal De Tullio ${ }^{4}$ \\ and Marie-Paule Mingeot-Leclercq ${ }^{1, *}$ \\ 1 Cellular and Molecular Pharmacology Unit, Louvain Drug Research Institute, Université catholique de \\ Louvain, Avenue E. Mounier 73, B1.73.05, 1200 Brussels, Belgium; jules.bayiha@gmail.com \\ 2 Laboratoire de Technologie Pharmaceutique et Biopharmacie, CIRM, Université de Liège, \\ 4000 Liège, Belgium; B.Evrard@uliege.be \\ 3 Laboratory of Tumor \& Development Biology, GIGA-Cancer, Université de Liège and CHU, \\ 4000 Liège, Belgium; Didier.Cataldo@uliege.be \\ 4 Laboratoire de Chimie Pharmaceutique, CIRM, Université de Liège, 4000 Liège, Belgium; \\ P.DeTullio@uliege.be \\ * Correspondence: marie-paule.mingeot@uclouvain.be
}

Academic Editors: Marina Isidori, Margherita Lavorgna, Rosa Iacovino and Georgia N. Valsami updates

Received: 11 August 2020; Accepted: 15 October 2020; Published: 22 October 2020

\begin{abstract}
Synthetic glucocorticoids such as budesonide (BUD) are potent anti-inflammatory drugs commonly used to treat patients suffering from chronic inflammatory diseases. A previous animal study reported a higher anti-inflammatory activity with a 2-hydroxypropyl- $\beta$-cyclodextrin $(\mathrm{HP} \beta \mathrm{CD}$ )-based formulation of BUD (BUD:HP $\beta C D$ ). This study investigated, on cellular models (A549 and A-THP-1), the effect of BUD:HP $\beta$ D in comparison with BUD and HP $\beta C D$ on the effects induced by oxidative and inflammatory stress as well as the role of cholesterol. We demonstrated the protective effect afforded by BUD:HP $\beta C D$ against cytotoxicity and ROS generation induced by oxidative and inflammatory stress. The effect observed for BUD:HP $\beta C D$ was comparable to that observed with $\mathrm{HP} \beta C D$ with no major effect of cholesterol content. We also demonstrated (i) the involvement of the canonical molecular pathway including ROS generation, a decrease in PI3K/Akt activation, and decrease in phosphorylated/unphosphorylated HDAC2 in the effect induced by BUD:HP $\beta C D$, (ii) the maintenance of IL-8 decrease with BUD:HP $\beta C D$, and (iii) the absence of improvement in glucocorticoid insensitivity with BUD:HP $\beta C D$ in comparison with BUD, in conditions where HDAC2 was inhibited. Resulting from HP $\beta C D$ antioxidant and anticytotoxic potential and protective capacity against ROS-induced PI3K/Akt signaling and HDAC2 inhibition, BUD:HP $\beta C D$ might be more beneficial than BUD alone in a context of concomitant oxidative and inflammatory stress.
\end{abstract}

Keywords: cyclodextrins; $\mathrm{HP} \beta C D$; budesonide; inflammation; ROS; Akt; HDAC; cholesterol

\section{Introduction}

Inhaled corticosteroids were first discovered 50 years ago and are used as anti-inflammatory drugs. They are very effective controllers of asthma and largely used in chronic obstructive pulmonary disease (COPD) to prevent exacerbations and improve quality of life in COPD patients [1,2] despite the appearance of corticosteroid insensitivity [3]. Several alternatives to glucocorticoids have been developed in the past few years [4-6] but efforts are still essential to address the lack of treatment 
options in COPD smoking patients for whom a loss of sensitivity to glucocorticoids is observed [7]. The cellular and molecular mechanisms underlying steroid insensitivity in severe asthma and COPD are still not fully understood [7]. Oxidative stress, an increase in phosphoinositide-3-kinase/Akt (PI3K/Akt) signaling leading to the phosphorylation of HDAC2, associated with a loss of HDAC2 activity, could be critical $[3,8]$.

Budesonide (BUD) is one of the most extensively used inhaled glucocorticoids including in the prophylactic management of asthma [9] and smoking-induced COPD [10,11]. However, frequent dosing remains a major concern in the use of budesonide. Moreover, the therapeutic potential of budesonide might be limited by its low solubility at a physiological $\mathrm{pH}$. The development of budesonide formulations that can enhance drug solubility and the dissolution rate in biological fluids will likely achieve higher tissue concentrations and effectiveness.

With the aim to improve the use of inhaled corticoids with sustained release, Dufour et al. [12] evaluated in a mouse model of asthma a new formulation where budesonide was complexed with cyclodextrin (2-hydroxypropyl- $\beta$-cycodextrin; HP $\beta C D)$. In a model of smoking-induced COPD in mammals, Cataldo et al. (Cataldo et al., Patent, 2014) suggested a potential interest in a pharmaceutical preparation resulting from the complexation of budesonide with HP $\beta C D$.

Cyclodextrins are typically cone-shaped cyclic oligosaccharides of six $(\alpha-C D)$, seven $(\beta-C D)$ or eight $(\gamma-C D)$ glucose units. They possess a hydrophobic cavity allowing them to host hydrophobic molecules. They are widely used as complexing agents for low water-soluble drugs to improve their physicochemical properties including solubility, bioavailability and stability, but they also have many other applications in food, cosmetics, or textiles, for example [13-16]. $\beta-C D$ and its derivatives can form a soluble inclusion complex with cholesterol and are often used to extract it from biological material [15]. Among $\beta-C D s$, methyl- $\beta-C D(M \beta C D)$ is the most effective and the most used method to extract cholesterol but has limited clinical application, unlike HP $\beta C D$ whose clinical application is broader [17-20].

The main anti-inflammatory mechanism of glucocorticoids involves the activation of glucocorticoid receptors in the cytosol after glucocorticoid binding, leading to their translocation to the nucleus, where they recruit histone deacetylase 2 (HDAC2) to the activated inflammatory gene complex. HDAC2 then reduces the acetylation of histones and glucocorticoid receptors, allowing chromatin condensation and the trans-repression of inflammatory transcription factors, respectively [21,22]. Through a decrease in activity and expression of HDAC2 in lung airways and alveolar macrophages, corticosteroid treatment is poorly effective for patients suffering from COPD [21,22]. Based on the characterized interaction between cyclodextrins and cholesterol, we hypothesized that this interaction could be involved in the effects of the BUD:HP $\beta C D$ complex. Cholesterol is largely known for its effect on biophysical membrane properties and cholesterol-enriched domains are linked to membrane signaling [23-26] including pathways involved in PI3K/Akt signaling and inflammation processes. On giant unilamellar vesicles (GUVs) and lipid monolayers, BUD:HP $\beta C D$ induced the disruption of cholesterol-enriched raft-like liquid ordered domains-an increase in membrane permeability and fluidity [27]. Except for membrane fluidity, all these effects were enhanced when HP $\beta C D$ was complexed with budesonide as compared with HP $\beta C D$ [27]. On cellular models, this could involve signal transduction pathways such as ROS generation, inflammatory cytokines expression and cell death.

The current study aimed to characterize the effect of the BUD:HP $\beta C D$ complex in comparison with BUD and HP $\beta C D$ on the response of human alveolar epithelial cells (A549) or human monocytes (A-THP1) to a mix of hydrogen peroxide and lipopolysaccharide $\left(\mathrm{H}_{2} \mathrm{O}_{2}+\mathrm{LPS}\right)$ mimicking stressful effects including those from cigarette smoke [28-30] or from environmental toxicants. In detail, we pursued four objectives: first, to establish the potential interest of BUD:HP $\beta C D$ on the cytotoxicity induced by oxidative and inflammatory stressors; second, to investigate the cellular effect of BUD:HP $\beta C D$ on the signaling pathway involved in corticosteroid effects including ROS generation, PI3K/Akt activation, HDAC2 activity and the release of pro-inflammatory cytokines such as IL-8; 
third, to question the role of cholesterol in the effect induced by BUD:HPBCD on ROS generation and PI3K/Akt activation, with the two first membranous events leading to inflammation, and fourth, to determine the effect of BUD:HP $\beta C D$ as compared to BUD in glucocortioid resistance and the role of HDAC2 in mediating the loss of the glucocorticoid anti-inflammatory effect.

This study is a part of the continuing efforts to develop novel drug delivery systems, as the complex between budesonide and cyclodextrins, with the aim to improve the treatment of patients suffering from smoking-induced COPD.

\section{Results}

\subsection{BUD:HP $\beta C D$ Complex and $\mathrm{HP} \beta C D$ Attenuate $\mathrm{H}_{2} \mathrm{O}_{2}+$ LPS-Induced Cytotoxicity}

Since alveolar cell death is one feature observed in the lung of patients suffering from smoking-induced COPD [31], the potential effect of BUD:HP $\beta C D$ on A549 human alveolar epithelial cells submitted to oxidant and inflammatory stressors was investigated. Cells were incubated with $\mathrm{H}_{2} \mathrm{O}_{2}+$ LPS for $2 \mathrm{~h}$. Cytotoxicity, as reflected by lactate dehydrogenase (LDH) release, was observed with a 1.7-fold increase as compared to untreated cells (Figure 1A). The increase in cytotoxicity between 2 and $6 \mathrm{~h}$ is low (1.8-fold at $6 \mathrm{~h}$ ) suggesting the cytotoxicity almost reached its maximum at $2 \mathrm{~h}$. $\mathrm{H}_{2} \mathrm{O}_{2}+$ LPS-induced cytotoxicity seemed to result from the addition of $\mathrm{H}_{2} \mathrm{O}_{2}$ and LPS.

The effect of the BUD:HP $\beta C D$ complex on cytotoxicity induced by $\mathrm{H}_{2} \mathrm{O}_{2}+$ LPS was followed. Incubation of A549 cells with the BUD:HP $\beta C D$ complex together with $\mathrm{H}_{2} \mathrm{O}_{2}+$ LPS induced a decrease in cytotoxicity (Figure 1D). This protective effect appeared to not evolve further after $2 \mathrm{~h}$ of incubation. A similar effect was recorded with $\mathrm{HP} \beta C D$ (Figure 1C), whereas BUD showed no effect whatever the dosage (Figure 1B). These results suggest that the BUD:HP $\beta C D$ complex and HP $\beta C D$ would have anticytotoxic potential against $\mathrm{H}_{2} \mathrm{O}_{2}+$ LPS-induced cytotoxicity in A549 cells.
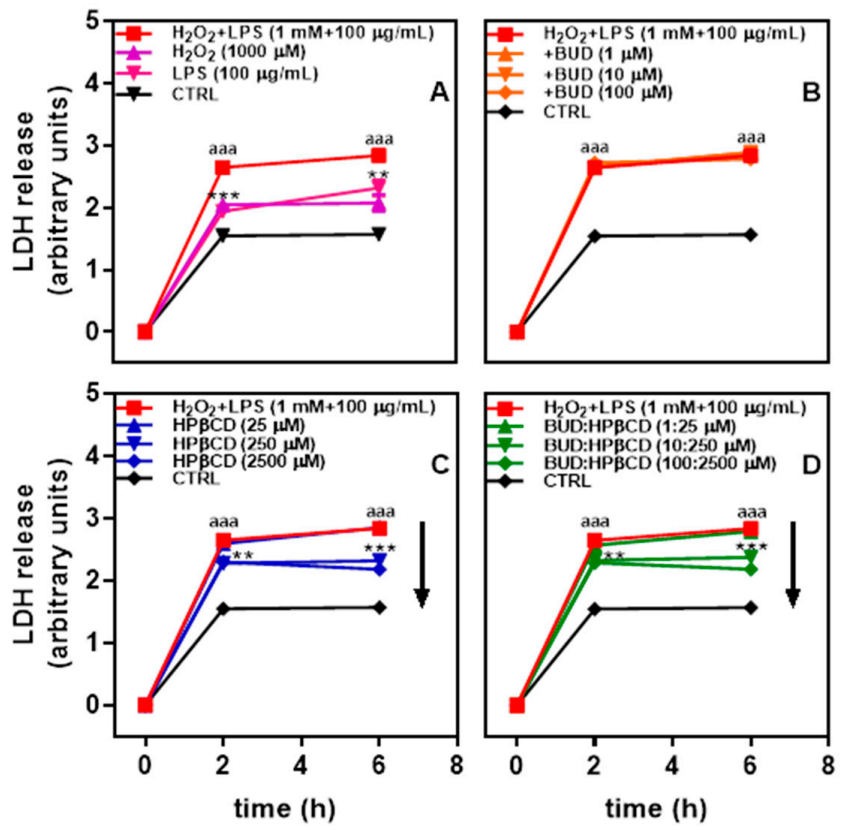

Figure 1. Lactate dehydrogenase (LDH) release after A549 cells incubation with $\mathrm{H}_{2} \mathrm{O}_{2}$, Lipopolysaccharides (LPSs), and $\mathrm{H}_{2} \mathrm{O}_{2}+$ LPS for up to $6 \mathrm{~h}$ (A) and effect of budesonide (BUD) (B), $\mathrm{HP} \beta \mathrm{CD}(\mathbf{C})$, and BUD:HP $\beta C D$ complex (D) on $\mathrm{H}_{2} \mathrm{O}_{2}+$ LPS-induced cytotoxicity. Each point represents the mean \pm SEM of at least 4 independent means of triplicated measures; where not visible, error bars are included in the symbol. The difference was considered significant for a $p$-value $<0.05$. (aaa) indicates $p<0.001$ versus untreated group; $\left(^{* *}\right)$ and $\left.{ }^{* * *}\right)$ corresponds to $p<0.01$ and 0.001 versus $\mathrm{H}_{2} \mathrm{O}_{2}$ +LPS-treated group, respectively. 
To determine if apoptosis is involved in the cell death process for which BUD:HP $\beta C D$ could protect, apoptosis was monitored by counting condensed/fragmented nuclei using HOECHST dye on $\mathrm{H}_{2} \mathrm{O}_{2}+$ LPS-treated cells. We also determined if the BUD:HP $\beta C D$ complex as well as BUD, and HP $\beta C D$ could attenuate apoptosis.

A549 cells were incubated for $2 \mathrm{~h}$ with $\mathrm{H}_{2} \mathrm{O}_{2}+$ LPS with/without BUD:HP $\beta C D$ in comparison with BUD or $\mathrm{HP} \beta C D$. $\mathrm{H}_{2} \mathrm{O}_{2}+$ LPS induced significant apoptosis, which appeared to result from the addition of the individual effects of $\mathrm{H}_{2} \mathrm{O}_{2}$ and LPS (Figure 2A). Concomitant incubation with each of the selected compounds induced a concentration-dependent decrease in $\mathrm{H}_{2} \mathrm{O}_{2}+$ LPS-induced apoptosis. These results suggest that the BUD:HP $\beta C D$ complex (Figure 2D) and HP $\beta C D$ (Figure 2C), at the highest selected dosages could protect cells against $\mathrm{H}_{2} \mathrm{O}_{2}+$ LPS-induced apoptosis in A549 cells. A non-significant decrease was observed with BUD (Figure 2B).

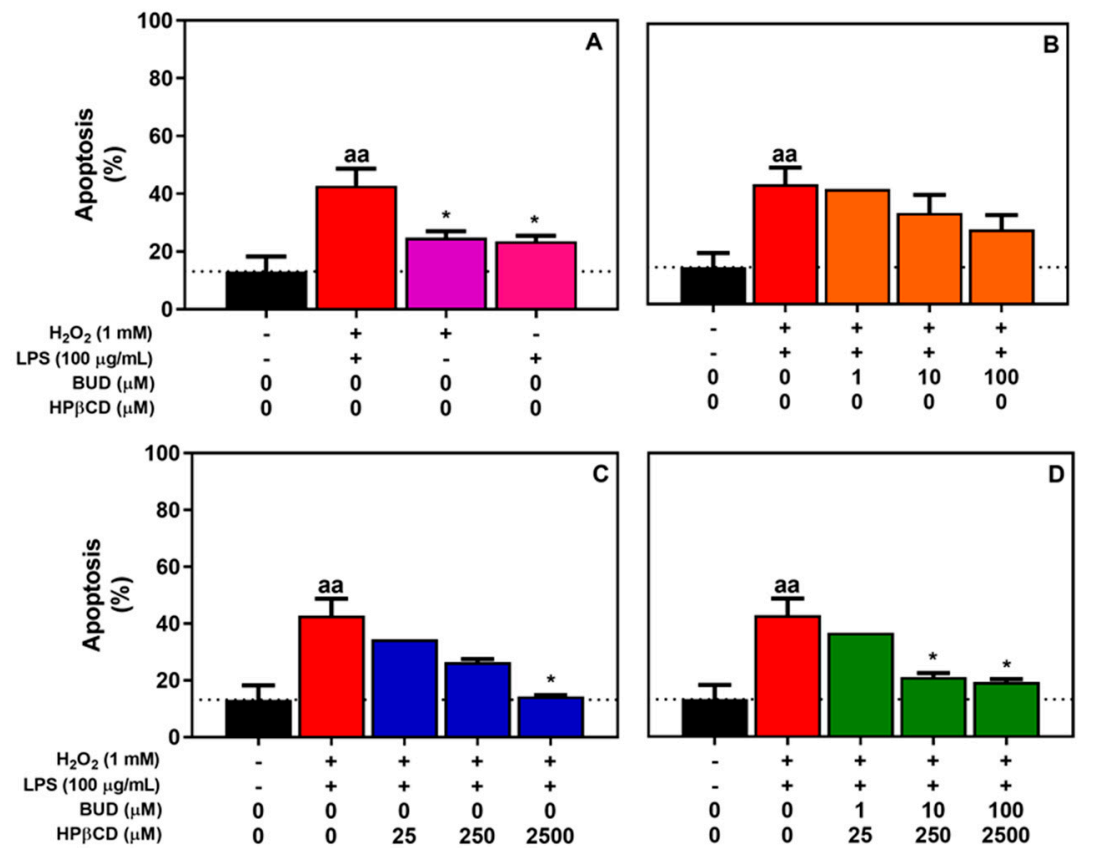

Figure 2. A549 cells apoptosis after treatment with $\mathrm{H}_{2} \mathrm{O}_{2}$, LPS, and $\mathrm{H}_{2} \mathrm{O}_{2}+$ LPS for $2 \mathrm{~h}(\mathbf{A})$ and effect of $\operatorname{BUD}(\mathbf{B}), \mathrm{HP} \beta \mathrm{CD}(\mathbf{C})$, and BUD:HP $\beta C D$ complex (D) on $\mathrm{H}_{2} \mathrm{O}_{2}+$ LPS-induced apoptosis. Apoptosis was quantified by counting condensed/fragmented nuclei after HOECHST staining. Each bar represents the mean of $3 \pm$ SEM or 2 independent measures. A one-way ANOVA with Dunett post-test was used to compare the mean of a test group with the mean of the untreated group or $\mathrm{H}_{2} \mathrm{O}_{2}+$ LPS-treated group. The difference was considered significant for a $p$-value $<0.05$. (aa) indicates $p<0.01$ versus untreated group, $\left(^{*}\right)$ indicates $p<0.05$ versus $\mathrm{H}_{2} \mathrm{O}_{2}+$ LPS-treated group.

2.2. BUD:HP $\beta C D$ Complex and HP $\beta C D$ Protect against $\mathrm{H}_{2} \mathrm{O}_{2}+$ LPS-Induced Oxidative Stress in A549 Cells: Dose and Time-Dependent Effects

Because oxidative stress is critical for numerous pathologies including smoking-induced COPD [32], and with the aim to understand the mechanism of action behind the effects observed with BUD:HP $\beta C D$, the potential antioxidant effect of the BUD:HP $\beta C D$ complex in A549 human alveolar epithelial cells was monitored. A549 cells were incubated for $2 \mathrm{~h}$ with a $\mathrm{H}_{2} \mathrm{O}_{2}+\mathrm{LPS}$ mix to model a concomitant oxidative and inflammatory environment. ROS generation induced by the BUD:HP $\beta C D$ complex was monitored in comparison with the effect induced by budesonide or HP $\beta C D$.

In comparison with control cells, we observed a 1.6-fold significant increase in intracellular ROS production when cells were incubated with $\mathrm{H}_{2} \mathrm{O}_{2}+$ LPS (Figure 3A) This effect was similar to the effect induced by treatment with $\mathrm{H}_{2} \mathrm{O}_{2}$ alone (1.5-fold increase), unlike the treatment with LPS alone, 
which did not show any significant effects, suggesting that $\mathrm{H}_{2} \mathrm{O}_{2}+$ LPS-induced oxidative stress would be mainly driven by $\mathrm{H}_{2} \mathrm{O}_{2}$ in A549 cells.

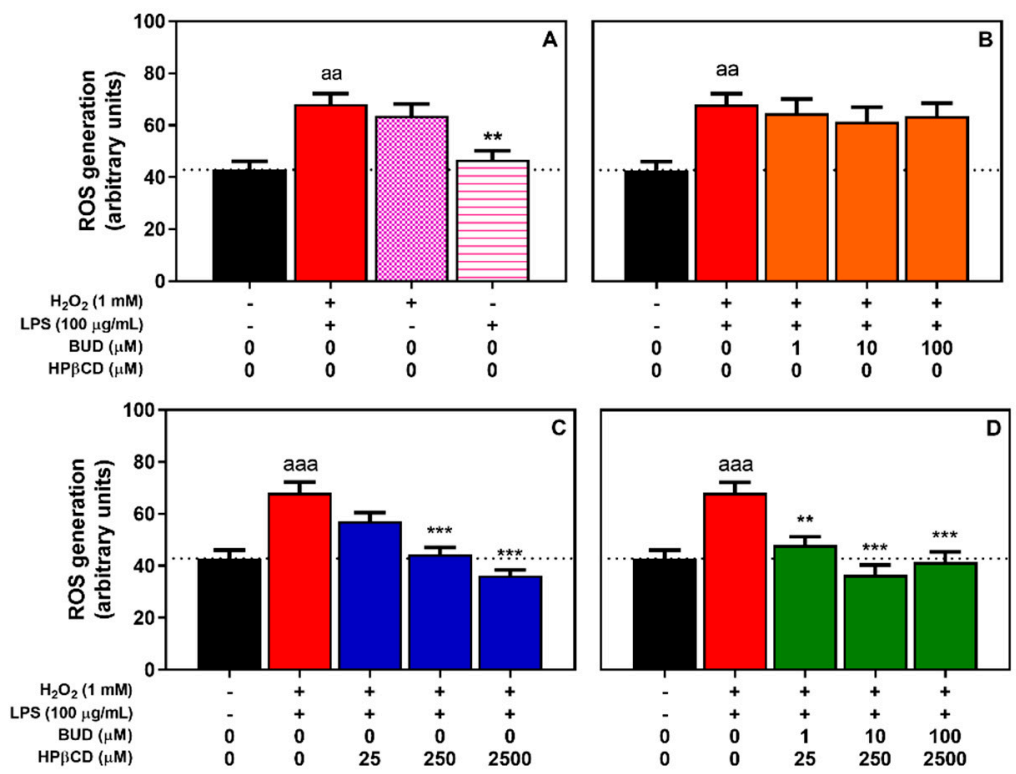

Figure 3. ROS generation in A549 cells after treatment with $\mathrm{H}_{2} \mathrm{O}_{2}$, LPS, or $\mathrm{H}_{2} \mathrm{O}_{2}+$ LPS for $2 \mathrm{~h}$ (A) and effect of BUD (B), $\mathrm{HP} \beta C D(\mathbf{C})$, and BUD:HP $\beta C D$ complex (D) on $\mathrm{H}_{2} \mathrm{O}_{2}$ + LPS-induced ROS generation. ROS generation was evaluated by measuring the fluorescence of dichlorofluorescein (DCF). Each bar represents the mean \pm SEM of 4 independent means of triplicated measures. A one-way ANOVA with Dunett post-test was used to compare the mean of a test group with the mean of untreated group or $\mathrm{H}_{2} \mathrm{O}_{2}$ + LPS-treated group. The difference was considered significant for a $p$-value $<0.05$. (aa), and (aaa), indicate $p<0.01$, and 0.001 versus untreated group, respectively); $\left.{ }^{* *}\right)$, and $\left({ }^{* * *}\right)$, correspond to $p<0.01$ and 0.001 versus $\mathrm{H}_{2} \mathrm{O}_{2}+$ LPS-treated group, respectively.

A concomitant incubation of A549 cells with $\mathrm{H}_{2} \mathrm{O}_{2}+$ LPS and increasing concentrations of the BUD:HP $\beta C D$ complex (1:25, 10:250, 100:2500 $\mu \mathrm{M}$; Figure 3D) was associated with a decrease in ROS production as compared with the experimental conditions in which the complex was not present. This suggests a protective effect of the BUD:HP $\beta C D$ complex against the oxidative stress induced by $\mathrm{H}_{2} \mathrm{O}_{2}+$ LPS. A similar effect was observed with increasing concentrations of HP $\beta C D(25-2500 \mu \mathrm{M}$; Figure 3C). In contrast no effect of BUD (1-100 $\mu \mathrm{M}$; Figure 3B) was observed.

Regarding the effect of time (Figure 4), ROS production in the presence of $\mathrm{H}_{2} \mathrm{O}_{2}+$ LPS was already marked after 30 min compared to untreated cells. This effect was maintained throughout the entire time period investigated $(6 \mathrm{~h})$ and seemed to evolve in parallel with untreated cells after $2 \mathrm{~h}$. When the BUD:HP $\beta C D$ complex was added together with $\mathrm{H}_{2} \mathrm{O}_{2}+$ LPS, a lowering effect on ROS production was observed throughout the entire time period investigated (Figure 4B). The extent of the effect depended upon the dose and was largely similar to the effect observed in the presence of HP $\beta C D$ (Figure 4 C). No significant change was observed after $2 \mathrm{~h}$ of incubation with $\mathrm{H}_{2} \mathrm{O}_{2}+$ LPS. Again, during the entire period investigated, no significant effect was observed in the presence of BUD (Figure 4A). Altogether, these results suggest that the BUD:HP $\beta C D$ complex and $\mathrm{HP} \beta C D$ have a similar antioxidant potential against $\mathrm{H}_{2} \mathrm{O}_{2}+$ LPS in A549 cells. 

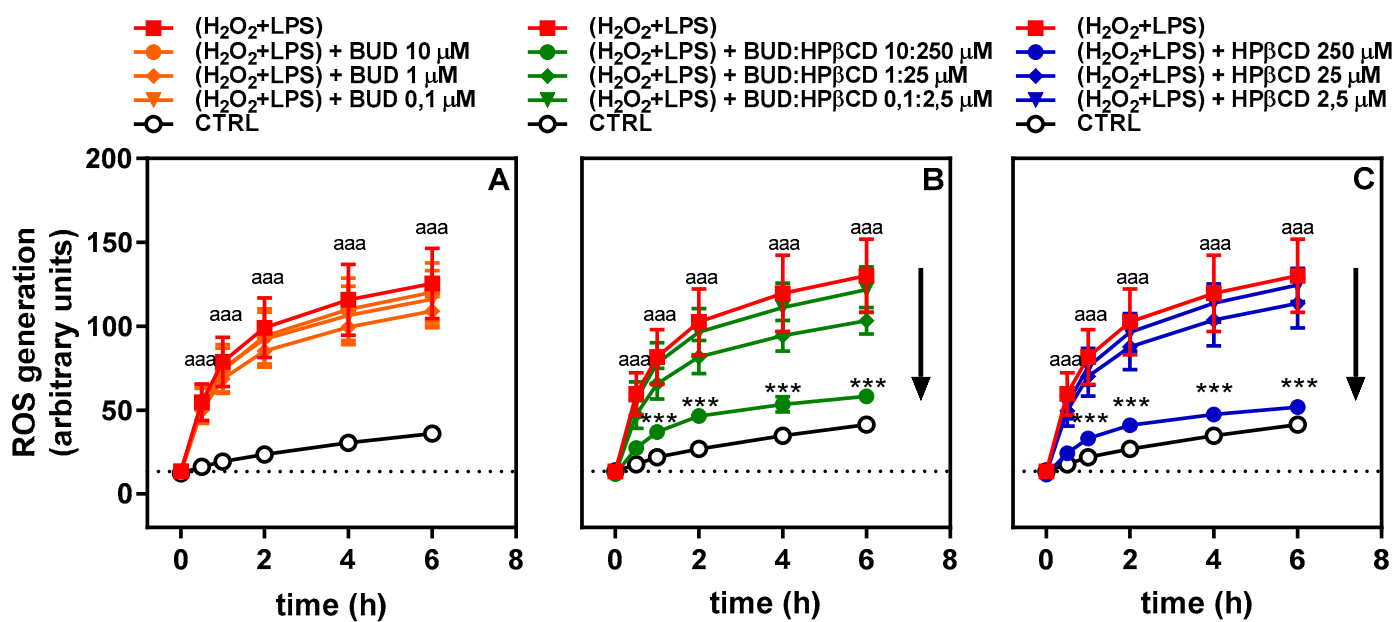

Figure 4. Effect of BUD (A), BUD:HP $\beta C D$ complex (B) and $\mathrm{HP} \beta C D(\mathbf{C})$ on $\mathrm{H}_{2} \mathrm{O}_{2}+$ LPS-induced ROS generation for 0 to $6 \mathrm{~h}$ of incubation. ROS generation was evaluated by measuring the fluorescence of dichlorofluorescein (DCF). Each bar represents the mean \pm SEM of 3 independent means of triplicated measures. These results and the results illustrated in Figure 3 are independent. When deviations are not visible they are too small to be seen. The difference was considered significant for a $p$-value $<0.05$. (aaa) corresponds to $p<0.001$ versus untreated group; $\left(^{* * *}\right)$ indicates $p<0.001$ versus $\mathrm{H}_{2} \mathrm{O}_{2}+$ LPS-treated group.

2.3. BUD:HP $\beta C D$ Complex and HP $\beta C D$ Attenuate $\mathrm{H}_{2} \mathrm{O}_{2}+$ LPS-Induced Phosphoinositide-3-Kinase/Akt Signaling in A549 Cells

Oxidative stress-induced glucocorticoid insensitivity involves an increase in PI3K/Akt signaling $[8,33,34]$ as reflected by Akt phosphorylation. To validate in in vitro model the relationship between oxidative stress and increase in PI3K/Akt signaling, the phosphorylation of Akt, in the absence or in the presence of antioxidants (N-acetyl-L-cysteine (NAC), vitamin C (Vit C)) and of a PI3K inhibitor (LY294002) (Figure 5A,C) was measured. An incubation of A549 cells with H2O2 + LPS for $2 \mathrm{~h}$ increased Akt phosphorylation. Concomitant incubation with NAC or vitamin C or LY294002 was associated with a lower phosphorylation of Akt (of approximately 36\% (NAC) and $65 \%$ (Vit C)) or a complete suppression of phosphorylation (LY294002) (Figure 5A,C). Regarding the effect of the BUD:HP $\beta C D$ complex or of $H P \beta C D$ at a concentration at which a significant antioxidant effect was observed, we demonstrated a decrease in Akt phosphorylation (Figure 5B,D). The decrease was approximately $32 \%$ both for the BUD:HP $\beta C D$ complex and for HP $\beta C D$ (Figure 5B,D). Thus, the BUD:HP $\beta C D$ complex and HP $\beta C D$ inhibited H2O2 + LPS-induced PI3K/Akt signaling increases in a similar way in A549 cells. 

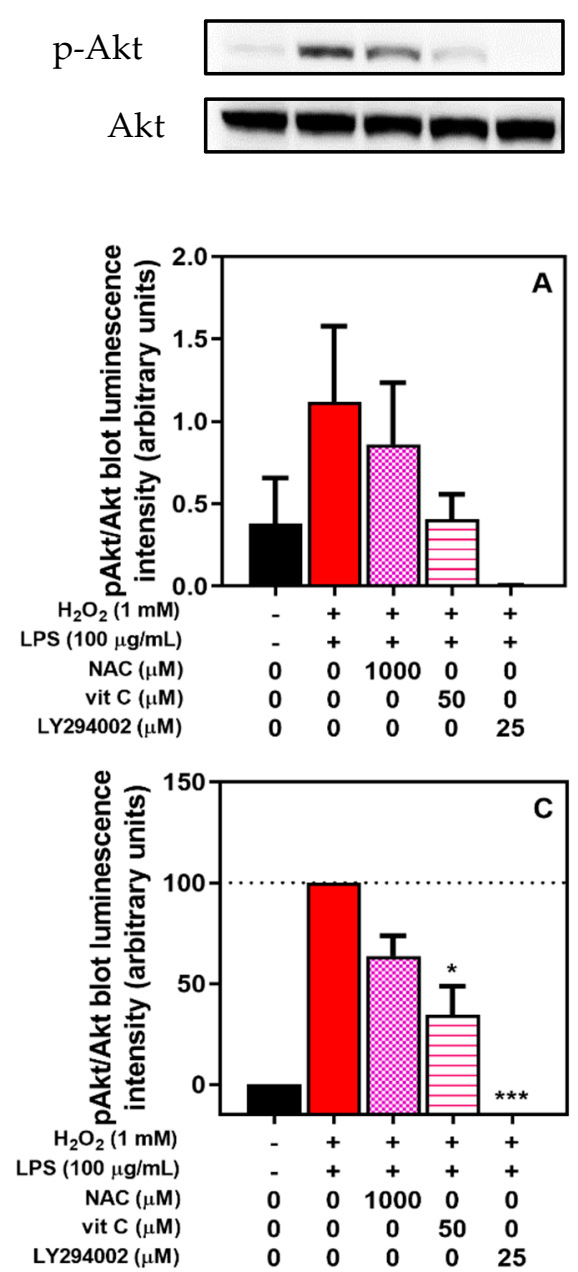

p-Akt

Akt
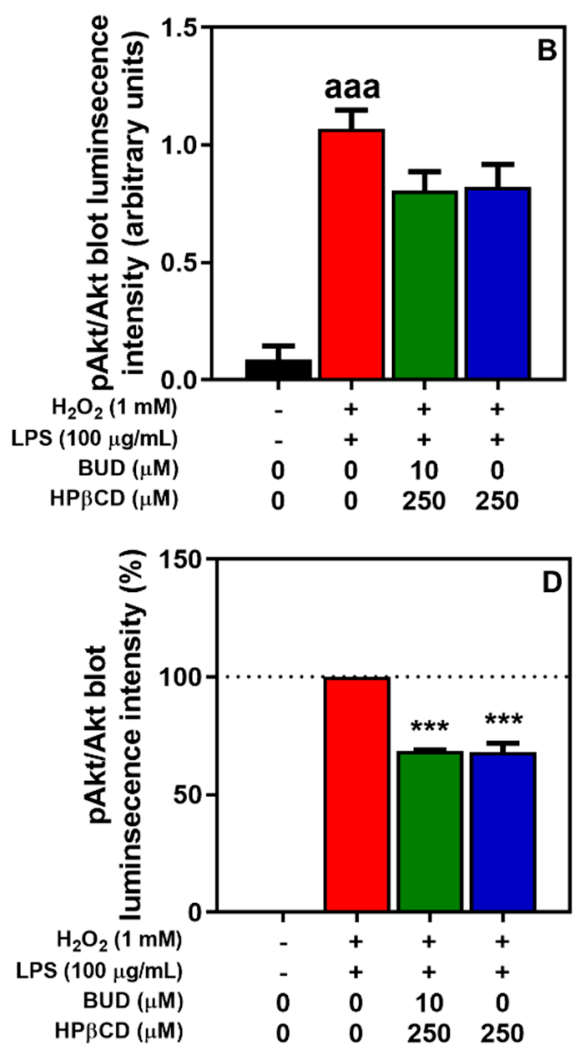

Figure 5. Akt phosphorylation induced by $\mathrm{H}_{2} \mathrm{O}_{2}+$ LPS in A549 cells. Effect of $N$-acetyl-L-cysteine (NAC), vitamin C (VitC) and LY294002 (A,C) and BUD:HP $\beta C D$ complex and HP $\beta C D(B, D)$ after $2 \mathrm{~h}$ of incubation. Data are expressed in absolute values (A/B; with representative blots) or in relative values (in comparison with the pAkt/Akt ration of cells incubated with $\mathrm{H}_{2} \mathrm{O}_{2}+\mathrm{LPS} ; \mathrm{C} / \mathrm{D}$ ). Akt phosphorylation was quantified after a Western blot by measuring the proportion of phosphorylated-Akt (p-Akt) blot luminescence intensity/total Akt (Akt) blot luminescence intensity. Each bar represents the mean of 3 independent measures. A one-way ANOVA with Dunett post-test was used to compare the mean of each test group with the mean of untreated group or $\mathrm{H}_{2} \mathrm{O}_{2}+$ LPS-treated group. The difference was considered significant for a $p$-value $<0.05$. (aaa) correspond to $p<0.001$ versus untreated group, $\left.{ }^{*}\right)$ and $(* * *)$ indicate $p<0.05$, and 0.001 versus $\mathrm{H}_{2} \mathrm{O}_{2}+$ LPS-treated group, respectively.

\subsection{Cholesterol Might Limit the Effects of BUD:HP $\beta C D$ Complex and HP $\beta C D$ in ROS Generation and PI3K/Akt Signaling Induced by $\mathrm{H}_{2} \mathrm{O}_{2}+\mathrm{LPS}$}

To give insight on the molecular mechanisms involved in the protective effect of BUD:HPBCD and $\mathrm{HPBCD}$, the potential role of cholesterol on ROS generation and PI3/Akt phosphorylation induced by $\mathrm{H}_{2} \mathrm{O}_{2}+$ LPS as well as the protective effects of the BUD:HP $\beta C D$ complex and HP $\beta C D$ were investigated. The rationale was derived from the ability of cyclodextrins to interact with cholesterol [35], the effects of BUD:HP $\beta C D$ and HP $\beta C D$ on the biophysical membrane properties of cholesterol-enriched domains [27], the importance of lipid-ordered domains enriched in cholesterol in membrane called rafts for ROS generation [36,37] and PI3K/Akt signaling [23,26]. 
2.4.1. Cholesterol Content Might Influence the Effects of the BUD:HP $\beta C D$ Complex and HP $\beta C D$ in ROS Generation Induced by $\mathrm{H}_{2} \mathrm{O}_{2}+$ LPS

In conditions where cholesterol was partly depleted (see Figure S1) we observed (Figure 6A) an increase in basal intracellular ROS levels, although non-significant. A greater and significant increase in $\mathrm{H}_{2} \mathrm{O}_{2}$ - and $\mathrm{H}_{2} \mathrm{O}_{2}+$ LPS-induced intracellular oxidant generation was also observed, suggesting that cholesterol content plays a role in $\mathrm{H}_{2} \mathrm{O}_{2}+$ LPS-related oxidative signaling in A549 cells.

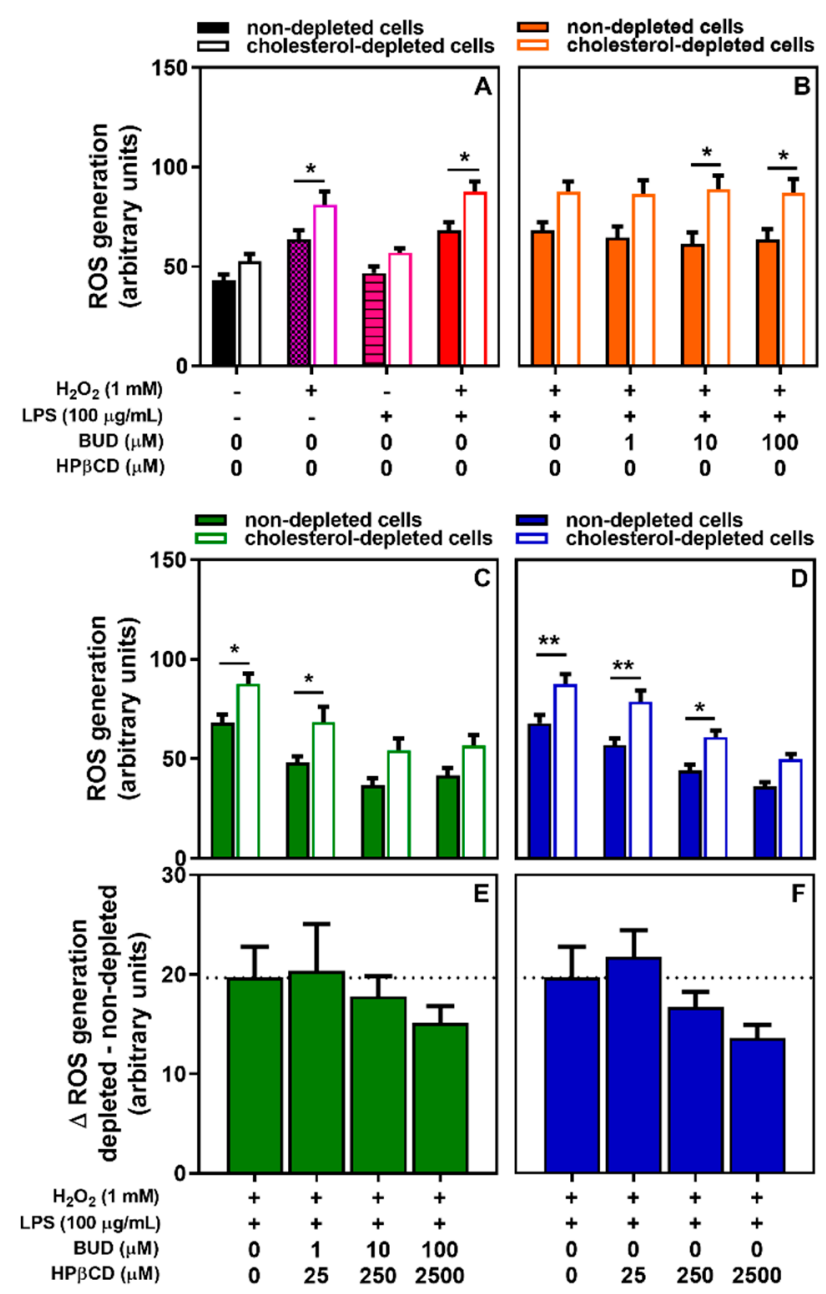

Figure 6. ROS generation in cholesterol-non-depleted or cholesterol-depleted A549 cells after treatment with $\mathrm{H}_{2} \mathrm{O}_{2}$, LPS, or $\mathrm{H}_{2} \mathrm{O}_{2}$ + LPS for $2 \mathrm{~h}$ (A) and effect of BUD (B), BUD:HP $\beta C D$ complex (C) and $\mathrm{HP} \beta C D(D)$ on $\mathrm{H}_{2} \mathrm{O}_{2}+$ LPS-induced ROS generation. Panels E and F show the difference $(\Delta)$ between the effect observed in cholesterol-depleted and -non-depleted cells of BUD:HP $\beta C D$ complex (E) and $\mathrm{HP} \beta C D(F)$ on $\mathrm{H}_{2} \mathrm{O}_{2}+$ LPS-induced oxidant generation after treatment for $2 \mathrm{~h}$. Each bar represents the mean \pm SEM of 4 independent means of triplicated measures. $\mathrm{H}_{2} \mathrm{O}_{2}+$ LPS-treated bar is the same for each panel. A one-way ANOVA with Dunett post-test was used to compare the mean of each test group in panels $(\mathbf{E}, \mathbf{F})$ with the mean of the $\mathrm{H}_{2} \mathrm{O}_{2}+$ LPS-treated group. A two-way ANOVA with Tukey multiple comparison post-test was used to compare the mean of non-depleted group with the mean of cholesterol-depleted group in the same concentration (panels A-D). The difference was considered significant for a $p$-value $<0.05$. $\left(^{*}\right)$ and $\left({ }^{* *}\right)$ indicate, respectively, $p<0.05$ and 0.01 between non-depleted and cholesterol-depleted group (panels A-D).

Compared to non-depleted cells, the ability of the BUD:HP $\beta C D$ complex (Figure 6C) and HP $\beta C D$ (Figure 6D) to protect against $\mathrm{H}_{2} \mathrm{O}_{2}+$ LPS-induced ROS production was preserved. Moreover, when the difference between $\mathrm{H}_{2} \mathrm{O}_{2}+$ LPS-induced ROS production in cholesterol-depleted and non-depleted cells 
was considered, a concentration-dependent increase in this protective effect was observed (Figure 6E,F), although this was non-significant. Again, no matter the cholesterol status of the cells, budesonide did not show any protective effects (Figure 6B). Thus, cholesterol content might influence the antioxidant effect of the BUD:HP $\beta C D$ complex and HP $\beta C D$.

In contrast with cholesterol, sphingomyelin, another major component from raft and also interacting with $\mathrm{HP} \beta \mathrm{CD}$ did not play a critical role on neither the oxidant generation induced by $\mathrm{H}_{2} \mathrm{O}_{2}+$ LPS nor on the ability of the BUD:HP $\beta C D$ complex and HP $\beta C D$ to protect against $\mathrm{H}_{2} \mathrm{O}_{2}+$ LPS-induced oxidant generation (Figure S2).

2.4.2. Cholesterol Limits the Effects of the BUD:HP $\beta C D$ Complex and HP $\beta C D$ in PI3K/Akt Signaling Induced by $\mathrm{H}_{2} \mathrm{O}_{2}+$ LPS

Since cholesterol-enriched plasma membrane domains may also play a critical role in the activation of PI3K/Akt signaling [23,25,26], which could be modulated by oxidative stress, the effect of cholesterol depletion on the protective effects of the BUD:HP $\beta$ CD complex and HP $\beta C D$ on the phosphorylation of Akt was studied. A decrease in Akt phosphorylation was preserved (Figure 7), without difference in cholesterol-depleted or not depleted cells.

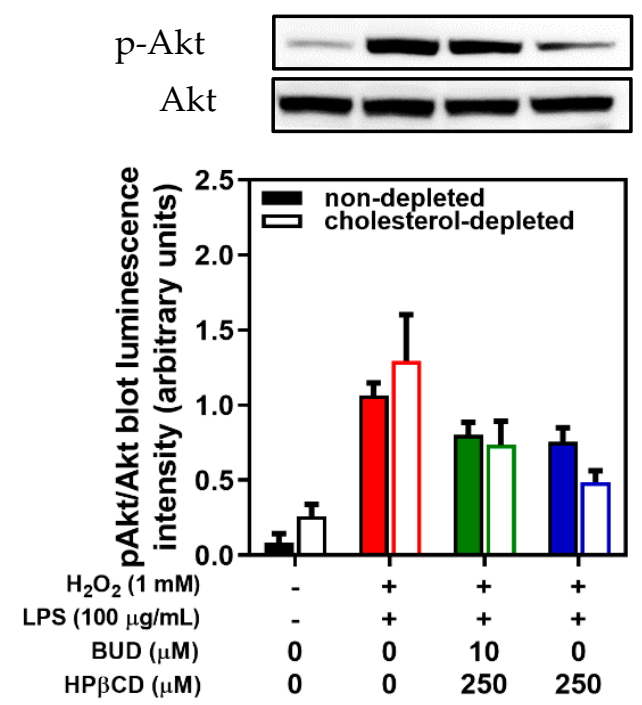

Figure 7. Effect of the BUD:HP $\beta C D$ complex versus $\mathrm{HP} \beta C D$ on $\mathrm{H}_{2} \mathrm{O}_{2}+$ LPS-induced Akt phosphorylation (p-Akt) in cholesterol-depleted and non-depleted A549 cells after $2 \mathrm{~h}$ of incubation with representative blot (cholesterol-depleted cells); each bar represents the mean of 3 independent measures.

2.5. BUD:HP $\beta C D$ Complex and HP $\beta C D$ Protect against $\mathrm{H}_{2} \mathrm{O}_{2}+$ LPS-Induced Increase in HDAC2 Phosphorylation in A549 Cells

The increase in PI3K/Akt signaling induced by oxidative stress results in the phosphorylation of HDAC2, a critical step in oxidative stress-related glucocorticoid insensitivity [38,39]. The relationship between oxidative stress and HDAC2 phosphorylation as well as the relationship between the increase in PI3K/Akt signaling and HDAC2 phosphorylation was investigated by using NAC and LY294002, respectively (Figure 8A,C). The treatment of A549 cells with $\mathrm{H}_{2} \mathrm{O}_{2}+$ LPS for $2 \mathrm{~h}$ was associated with an increase in phosphorylated HDAC2. Concomitant incubation with NAC or LY294002 was associated with a lower phosphorylation of HDAC2 of approximately 62\% (NAC) and 40\% (LY294002) (Figure 8A,C). This confirms that $\mathrm{H}_{2} \mathrm{O}_{2}+$ LPS increases HDAC2 phosphorylation through a mechanism involving oxidative stress and PI3K/Akt signaling in A549 cells.

A concomitant incubation with the BUD:HP $\beta C D$ complex or $\mathrm{HP} \beta C D$ with $\mathrm{H}_{2} \mathrm{O}_{2}+$ LPS was associated with a lower phosphorylation of HDAC2 of approximately $53 \%$ (BUD:HP $\beta C D)$ and $74 \%$ 
(HP $\beta C D$ ) (Figure 8B,D). Thus, the BUD:HP $\beta C D$ complex and HP $\beta C D$ inhibited the decrease in HDAC2 activity induced by $\mathrm{H}_{2} \mathrm{O}_{2}+$ LPS treatment in A549 cells with a higher effect induced by HP $\beta C D$.
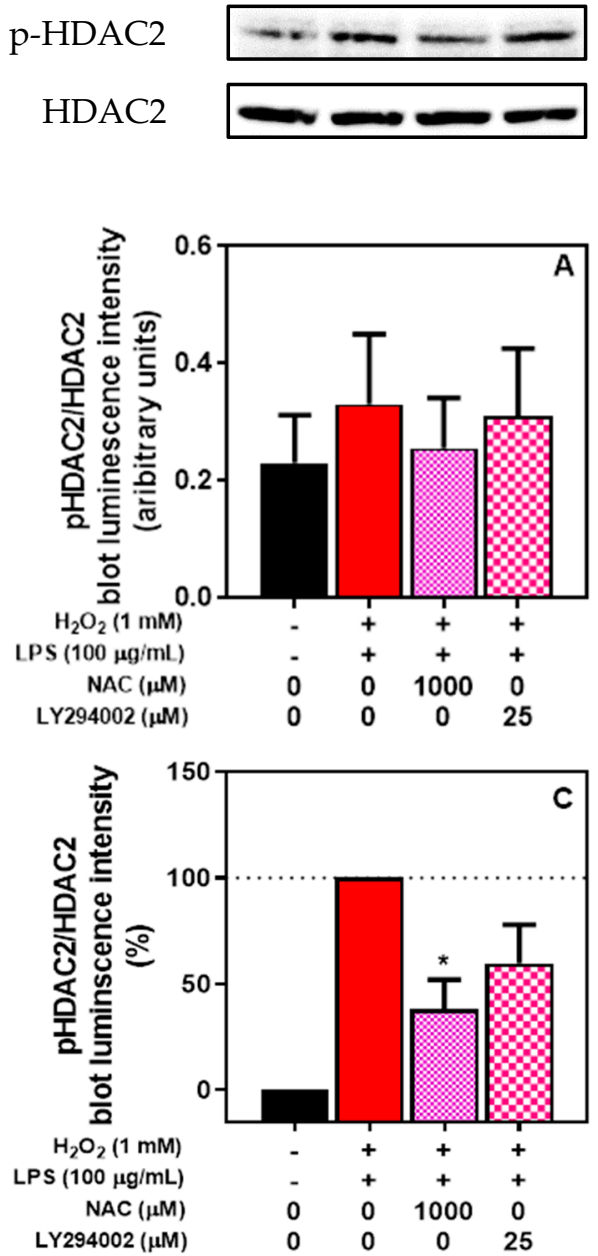
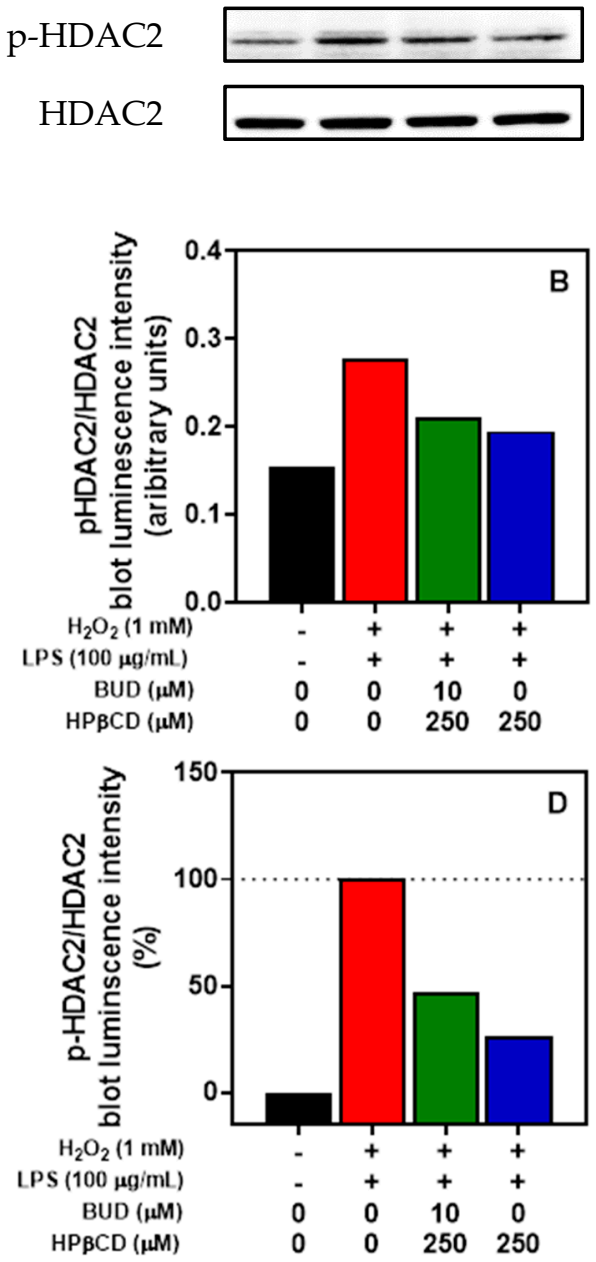

Figure 8. HDAC2 phosphorylation induced by $\mathrm{H}_{2} \mathrm{O}_{2}+$ LPS in A549 cells. Effect of NAC and LY294002 (A) and the BUD:HP $\beta C D$ complex versus $\operatorname{HP} \beta C D(B)$ after $2 \mathrm{~h}$ of incubation. Data are expressed in absolute values (A/B; with representative blots) or in relative values (in comparison with the pHDAC2/HDAC2 ration of cells incubated with $\mathrm{H}_{2} \mathrm{O}_{2}+$ LPS; C/D). HDAC2 phosphorylation was quantified after a Western blot by measuring the proportion of phosphorylated-HDAC2 (p-HDAC2) blot luminescence intensity/total HDAC2 (HDAC2) blot luminescence intensity. Each bar represents the mean of $3 \pm$ SEM or 2 independent measures. A one-way ANOVA with Dunett post-test was used to compare the mean of each test group with the mean of the control group $\left(\mathrm{H}_{2} \mathrm{O}_{2}+\right.$ LPS-treated group). The difference was considered significant for a $p$-value $<0.05$. $\left({ }^{*}\right)$ indicate $p<0.05$ versus control group.

\subsection{BUD:HP $\beta C D$ Complex and HP $\beta C D$ Attenuate $\mathrm{H}_{2} \mathrm{O}_{2}+$ LPS-Induced Inflammatory Response in THP-1 Cells}

Since persistent inflammatory response in the lung is a major feature of smoking-induced COPD [31], the anti-inflammatory potential of the BUD:HP $\beta C D$ complex in comparison with BUD or HP $\beta C D$ was evaluated. Thus, the effect of the BUD:HP $\beta C D$ complex, BUD or HP $\beta C D$ on $\mathrm{H}_{2} \mathrm{O}_{2}+$ LPS-induced IL-8 release in A549 cells and TH-P1 cells was determined. Because A549 cells appeared not sensitive to LPS [40], phorbol myristate acetate-activated THP-1 (A-THP-1) cells [41], a widely used model for human monocytes, which are highly sensitive to LPS treatment, were used. For the sake of comparison, we also treated A549 cells with TNF- $\alpha$ for inflammatory stress. 
First, the incubation of A-THP-1 cells with $\mathrm{H}_{2} \mathrm{O}_{2}+$ LPS for $2 \mathrm{~h}$ was significantly associated with an 8.6-fold increase in IL-8 release (Figure 9A). Treatment with LPS alone induced a significant 6.6-fold increase, whereas $\mathrm{H}_{2} \mathrm{O}_{2}$ alone did not induce any effects on IL-8 expression [41].

Concomitant incubation of the BUD:HP $\beta$ CD complex with $\mathrm{H}_{2} \mathrm{O}_{2}+$ LPS was associated with a lower release of IL-8 of approximately $45 \%$ no matter the concentration of the BUD:HP $\beta C D$ complex used (Figure 9D). In the presence of BUD, a decrease in of IL-8 release was also observed. The effect was similar with that induced by the BUD:HP $\beta C D$ complex (budesonide 1 and $10 \mu \mathrm{M}$ ), but higher at higher budesonide concentration $(100 \mu \mathrm{M})(67 \%)$ (Figure $9 \mathrm{~B})$. The presence of HP $\beta$ CD was also associated with a non-dependent dose-type decrease in IL-8 release. The effect was slightly lower as compared to BUD and the BUD:HP $\beta C D$ complex (approximately 34\%) (Figure 9C). These results suggest that the BUD:HP $\beta C D$ complex and BUD have similar anti-inflammatory properties, except at high concentrations at which budesonide was more efficient.

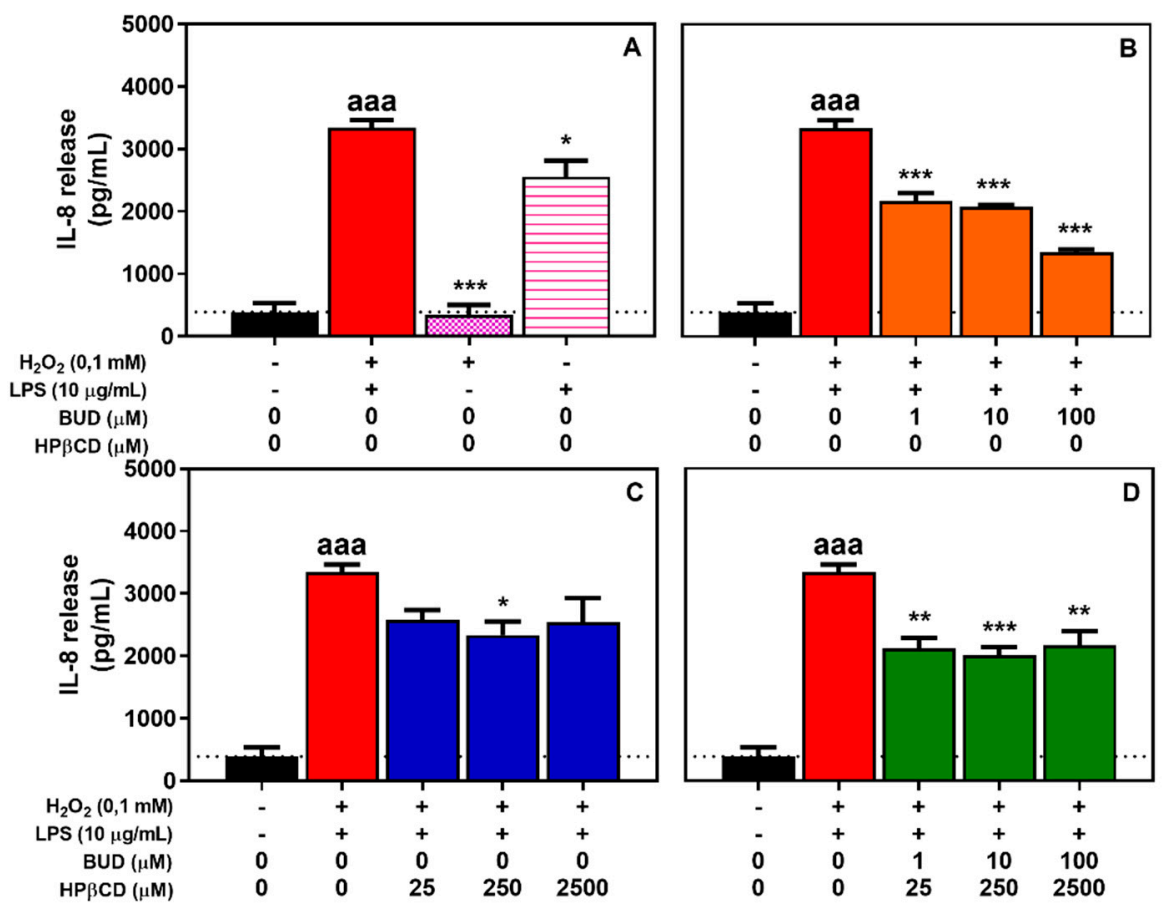

Figure 9. IL-8 release by A-THP-1 cells after treatment with $\mathrm{H}_{2} \mathrm{O}_{2}$, LPS or $\mathrm{H}_{2} \mathrm{O}_{2}+$ LPS for $2 \mathrm{~h}$ (A) and effect of BUD (B), HP $\beta C D(C)$, and BUD:HP $\beta C D$ complex (D) on $\mathrm{H}_{2} \mathrm{O}_{2}+$ LPS-induced IL-8 release. IL-8 release was measured in the extracellular medium by sandwich ELISA. Each bar represents the mean \pm SEM of 3 independent means of triplicated measures. A one-way ANOVA with Dunett post-test was used to compare the mean of each test group with the mean of untreated group or $\mathrm{H}_{2} \mathrm{O}_{2}+$ LPS-treated group. The difference was considered significant for a $p$-value < 0.05; (aaa), indicate $p<0.001$ versus untreated group; $\left({ }^{*}\right),\left({ }^{* *}\right)$, and $\left({ }^{* * *}\right)$ correspond to $p<0.05,0.01$ and 0.001 versus $\mathrm{H}_{2} \mathrm{O}_{2}+$ LPS-treated group, respectively.

A similar effect on IL-8 release was reported when comparing the effect of TNF $\alpha$ on A549 cells with the effect LPS on A-THP1. An anti-inflammatory potential of BUD $(1 \mu \mathrm{M})$ and the BUD:HP $\beta C D$ complex $(1: 25 \mu \mathrm{M})$ was observed with a lower potential of HP $\beta C D$ to decrease IL-8 release (Figure 10). 


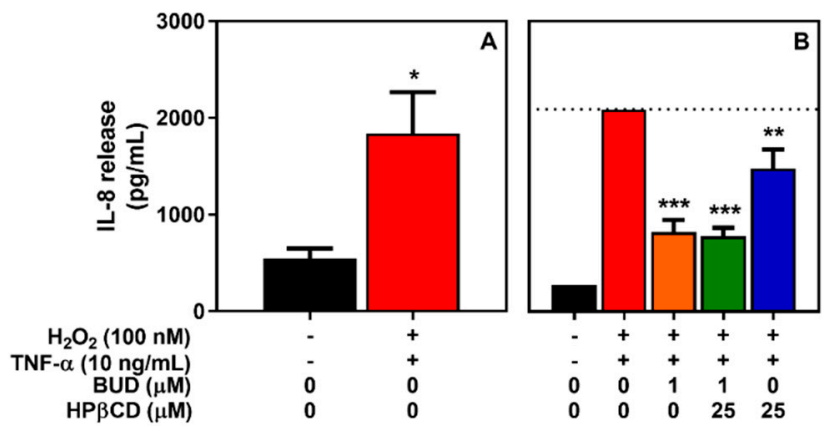

Figure 10. IL-8 release by A549 cells after treatment with $\mathrm{H}_{2} \mathrm{O}_{2}+$ TNF- $\alpha$ for $2 \mathrm{~h}$ (A) and effect of the BUD:HP $\beta C D$ complex versus BUD and $\mathrm{HP} \beta C D$ on $\mathrm{H}_{2} \mathrm{O}_{2}+\mathrm{TNF}-\alpha$-induced IL- 8 release (B). IL- 8 release was measured in the extracellular medium by sandwich ELISA. Results on panel B were normalized relative to untreated cells $(0 \%)$ and $\mathrm{H}_{2} \mathrm{O}_{2}+\mathrm{TNF}-\alpha$-treated cells $(100 \%)$. Each bar represents the mean \pm SEM of 3 independent means of triplicated measures. $\left(^{*}\right),\left({ }^{* *}\right)$, and $\left({ }^{* * *}\right)$, indicate, respectively, $p<0.05,0.01$, and 0.001 versus non-treated cells (A) or $\mathrm{H}_{2} \mathrm{O}_{2}+$ LPS-treated cells (B).

As HDAC2 is recruited by the activated glucocorticoid receptor to repress the transcription of proinflammatory genes [42] and to study the potential role of HDAC2 in the protection afforded by the BUD:HP $\beta C D$ complex in comparison with BUD or HP $\beta C D$ on IL-8 release, IL-8 release induced by TNF- $\alpha$ in conditions where cells were preincubated with or without trichostatin, a pharmacological HDAC2 inhibitor [43], was measured. We pretreated for $30 \mathrm{~min}$ A549 cells with increasing concentrations of trichostatin (0-250 nM) and determined IL-8 release after incubation for $2 \mathrm{~h}$ of cells with TNF- $\alpha$ (20 ng/mL) and BUD:HP $\beta C D$ complex or BUD or HP $\beta C D$ (Figure 11).

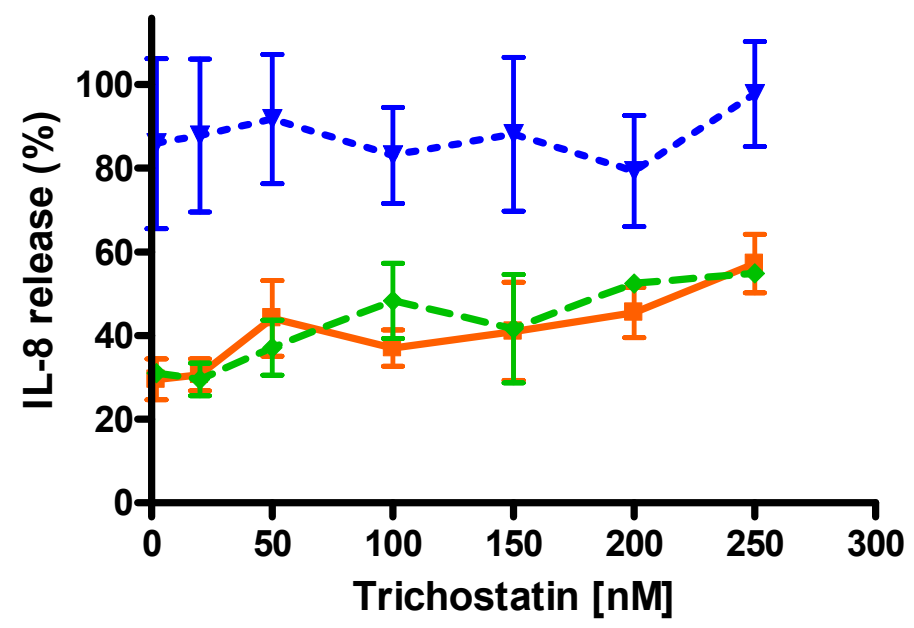

Figure 11. Percentage of IL-8 released after A549 cells pretreatment for 30 min with trichostatin (TSA) and incubation for $2 \mathrm{~h}$ with TNF- $\alpha$ in presence of BUD:HP $\beta C D$ complex, BUD or HP $\beta C D$. Results are expressed in percentage of IL- 8 released. $100 \%$ corresponds to cells preincubated for 30 min with TSA and incubated for $2 \mathrm{~h}$ with TNF- $\alpha$ only. IL-8 release was measured in the extracellular medium by sandwich ELISA. Data are from 3 independent experiments in triplicates. $\nabla H P \beta C D ; \diamond$ BUD:HP $\beta C D ; \square$ BUD.

IL-8 release induced by TNF $\alpha$ was markedly reduced (around 70\%) by BUD and BUD:HP $\beta C D$ whereas HP $\beta C D$ alone did not shown any effect or a very slight effect. When trichostatin was used in preincubation to inhibit the HDAC2 activity, the IL-8 release was increased, in a dose-dependent fashion in the presence of BUD or BUD:HP $\beta C D$. BUD:HP $\beta C D$ failed to improve the response of glucocorticoids in the condition of HDAC2 inhibition. Again, no or a very slight effect was observed with HP $\beta C D$ (Figure 11). 


\section{Discussion}

In animal models, Dufour et al. [12] suggested that budesonide (BUD) complexed with 2-hydroxypropyl- $\beta$-cyclodextrin (HP $\beta C D$ ) might be an alternative to BUD alone in the treatment of smoking-induced COPD. The current study was designed to characterize the effect of the BUD:HP $\beta C D$ complex on the response of human alveolar epithelial cells (A549) or human monocytes (A-THP1) to a mix of hydrogen peroxide and lipopolysaccharides $\left(\mathrm{H}_{2} \mathrm{O}_{2}+\right.$ LPSs $)$ mimicking stressful effects including those from cigarette smoke $[28,44,45]$ or from environmental toxicants. We characterized the effect of the BUD:HP $\beta C D$ complex on (i) ROS generation (oxidative stress), (ii) Akt phosphorylation (PI3K/Akt signaling activation), (iii) HDAC2 phosphorylation (HDAC2 inhibition of activity), and (iv) IL-8 release (inflammatory response) in comparison with the effects induced by BUD or HP $\beta C D$.

We demonstrated the protective effect afforded by BUD:HP $\beta C D$ against cytotoxicity and ROS generation induced by oxidative and inflammatory stress in comparison with BUD. The effect observed for BUD:HPBCD was comparable to that observed with HPBCD and might be limited by cholesterol. We also demonstrated (i) the involvement of the canonical molecular pathway including ROS generation, decrease in PI3K/Akt activation, decrease in HDAC2 activity and insensitivity to glucocorticoid in the effect induced by BUD:HP $\beta C D$, (ii) maintenance of IL-8 decrease with BUD:HP $\beta C D$ - even BUD at a high concentration $(100 \mu \mathrm{M})$ induced a slightly higher effect-and (iii) the absence of improvement in glucocorticoid insensitivity with BUD:HP $\beta C D$ in comparison with BUD, in conditions where HDAC2 was inhibited.

Improvement of cell viability after oxidative and inflammatory stress induced by BUD:HP $\beta C D$ is likely due to HP $\beta C D$ and linked to a decrease in ROS generation. The literature has reported that cyclodextrins, including HP $\beta C D$, may improve the toxicological profile of drugs by complexing them [46,47]. Additionally, the antioxidant potential of HP $\beta C D$ has been reported. Anraku et al. [48] showed HP $\beta C D$ remove pro-oxidants such as uremic toxins from the blood in a rat model of chronic renal failure. Zimmer et al. [49] showed that HP $\beta C D$ decreases aortic ROS generation in a mouse model of atherosclerosis. Other reports reviewed by López-Nicolás et al. [50] described HP $\beta C D$ as a protective agent of lipophilic nutrients and antioxidants against oxidation in foods. The demonstration of $\mathrm{HP} \beta C \mathrm{D}^{\prime}$ s antioxidant potential is interesting given the major role played by oxidative stress in numerous pathologies including COPD [51]. Here, the molecular mechanism leading to a decrease in ROS is still unclear but a direct effect through the interaction of $\mathrm{HP} \beta C D$ with $\mathrm{H}_{2} \mathrm{O}_{2}$ (Figure S3) is unlikely.

An indirect effect through changes in biophysical membrane properties could be suggested as an alternative explanation. We initially suggested that membrane cholesterol would play a major role in the occurrence of BUD:HP $\beta C D$-related cytoprotective effects. It has been extensively demonstrated that $\beta C D$ s, including $H P \beta C D$, can interact with lipid membranes, and change membrane biophysical properties $[17,35]$ closely related to signal transduction. This agrees with our previous experiments on giant unilamellar vesicles (GUVs), since we demonstrated BUD:HP $\beta C D$ and HP $\beta C D$ disrupted the liquid-disordered/liquid-ordered (Ld/Lo) phase separation observed in the presence of cholesterol for the benefit of the Ld phase, a process hindered in the presence of cholesterol [27]. Here, we observed an increase in BUD:HP $\beta C D$-related antioxidant effects in cholesterol-depleted cells suggesting that cholesterol might hinder ROS generation. The BUD:HP $\beta C D$-related antioxidant effect was preserved and even increased in cells partially depleted in cholesterol (50\% cholesterol depletion after $30 \mathrm{~min}$ exposition to $\mathrm{M} \beta \mathrm{CD}$ at $5 \mathrm{mM}$; no or very small cholesterol depletion induced by $\mathrm{HP} \beta C D$ for $2 \mathrm{~h}$ at the highest concentrations used in this work; Figure S4). Extracellular mechanisms are unlikely since we observed (i) no cellular uptake of HPßCD over the entire incubation period (Figure S5), and (ii) no neutralization of extracellular signals potentially responsible for oxidative stress, namely $\mathrm{H}_{2} \mathrm{O}_{2}$ and free radicals (Figure S3). BUD:HP $\beta C D$ and HP $\beta C D$-related cytoprotective effects could be seen as a membrane-mediated mechanism involving membrane lipid disorganization with limited lipid extraction after $2 \mathrm{~h}$ (cholesterol extraction induced by BUD:HP $\beta$ CD or HP $\beta C D$ reached 18\% and 12\%, 
respectively, while no cholesterol extraction in cholesterol-depleted cells was observed (Figure S4)), agreeing with the work of Lopez et al. [52].

One remaining question is the cross-talk between the antioxidant effect and inhibiting effect on oxidant-induced PI3K/Akt signaling. NAC and Vit C concentrations that inhibit more than $75 \%$ of ROS generation after $2 \mathrm{~h}$ of incubation (Figure 66 ) showed a protective effect against $\mathrm{H}_{2} \mathrm{O}_{2}+$ LPS-induced increase in PI3K/Akt signaling of about $36 \%$ (NAC) and $\sim 65 \%$ (Vit C). The effect was not related to the effect of LPS which might induce an increase in PI3K/Akt signaling $[53,54]$ since we observed that $\mathrm{H}_{2} \mathrm{O}_{2}+$ LPS-induced increase in PI3K/Akt signaling was almost exclusively associated with the presence of $\mathrm{H}_{2} \mathrm{O}_{2}$ (Figure S7). The activity of endogenous antioxidant enzymes $\mathrm{GSH}$ peroxidase against $\mathrm{H}_{2} \mathrm{O}_{2}$ [55], difference in the location within the bilayer between the effect induced by BUD:HPBCD and the location of enzymes involved in ROS generation or PI3K/Akt activation could be also involved.

Focusing on the final attempt for BUD:HPBCD, meaning its ability to decrease the release of inflammatory cytokines after oxidant and inflammatory stress, we could have expected a higher anti-inflammatory effect of the BUD:HP $\beta C D$ complex compared to the BUD alone. Dufour et al. [12] in a murine asthma model showed that similar anti-inflammatory effects could be obtained with a 2.5-fold lower BUD concentration when given as a complex with HP $\beta C D$. Zimmer et al. [49] reported anti-inflammatory effects of $\mathrm{HP} \beta C D$ in vivo in a mice model of atherosclerosis. At the cellular level, George et al. [56] assumed an anti-inflammatory property of HP $\beta C D$ after showing that its presence along with plasticized poly(vinyl chloride) (PVC) reduced LPS-induced TNF- $\alpha$ expression in human monocyte-like U937 cells while PVC alone had no effect. Matassoli et al. [57] showed that HP $\beta C D$ can inhibit LPS-induced TNF- $\alpha$ secretion in primary human monocytes. The higher effect on reduction of IL-8 release induced by BUD at a high concentration $(100 \mu \mathrm{M})$ as compared to the effect of BUD:HP $\beta C D$ could be linked to an inflammatory effect observed at high doses of HP $\beta C D$ [58]. Cell-type cellular components of inflammation [59] and changes in the release of BUD from HP $\beta C D$ hydrophobic cavity, depending upon the concentrations, could also play a role.

Lastly, in a potential translational perspective, the design of studies and concentrations have to be questioned. First, cells were exposed with BUD and $\mathrm{H}_{2} \mathrm{O}_{2}+$ LPS at the same time, meaning that BUD had time to prevent the inflammatory response before the decrease in glucocorticoid sensitivity induced by oxidative stress could take place. We reproduced experiments by changing the time course and by preincubating cells for $30 \mathrm{~min}$ with the oxidant and inflammatory stress before the incubation of cells with BUD:HP $\beta C D$ for $2 \mathrm{~h}$. No differences were observed. Another critical parameter would be the equilibrium between the free and bound forms of BUD or HPBCD [60]. In the presence of a lipophilic membrane, drug partitioning from the complex into the membranes can occur, promoting drug release from the $C D$ hydrophobic cavity. The latter point agrees with our work. Indeed, we showed that in pure phospholipid monolayers there is an increase in membrane surface pressure with the BUD:HP $\beta C D$ complex but not with HP $\beta C D$. This increase is usually associated with the insertion of a molecule within the monolayer. Since the only difference between HP $\beta C D$ and the BUD:HP $\beta C D$ complex is the presence of BUD, we could assume that BUD was inserted within the membrane. The critical importance of the equilibrium between free and complexed budesonide was also evidenced when we determined the effect of a mix of BUD and HP $\beta C D$ on IL-8 release for cells treated with increasing concentrations of trichostatin, a pharmacological inhibitor of HDAC2. The protective effect against IL-8 release of the mixture was higher than that afforded by the complex (Figure S8).

Second, BUD concentrations and/or amount of oxidant and inflammatory stressors used are relevant for patho-physio-logical conditions. BUD dry powder for inhalation (Pulmicort ${ }^{\circledR}$ ), was recommended for COPD patient administration - up to $1000 \mu \mathrm{g} /$ day on average. If we assume that about $30 \%$ of the nominal dose inhaled with a dry powder inhaler might reach the lungs [61,62], therefore $300 \mu \mathrm{g}$ of BUD dry powder in Pulmicort ${ }^{\circledR}$ administered in patients might reach the lungs. If the $300 \mu \mathrm{g}$ of BUD will disperse in the lung lining fluid (20-40 mL in a human of $70 \mathrm{~kg}$ ) [63], then the pulmonary BUD concentration could be approximately $17-35 \mu \mathrm{M}$, which is in the range of concentrations used in our study $(1-100 \mu \mathrm{M})$. However, we must remain cautious since the amount of 
BUD deposited in the lung is difficult to predict. The question of the relevance of the quantity of $\mathrm{H}_{2} \mathrm{O}_{2}$ + LPS is also raised. Here again, it appears difficult to properly assess the exposition of alveolar cells to $\mathrm{H}_{2} \mathrm{O}_{2}$ and LPS during smoking-e.g., many factors should be considered, such as the frequency of smoking, the number and type of cigarettes smoked per day, the duration of smoking, the distribution of smoke in the lungs, the half-life of each molecular species generated in cigarette smoke, their own biodisponibility, and so on. Nakayama et al. [28] and Hasday et al. [45], respectively, reported that extract amounts of $\mathrm{H}_{2} \mathrm{O}_{2}$ ranging from $500 \mathrm{nmol}$ to $4 \mu \mathrm{mol}$ of $\mathrm{H}_{2} \mathrm{O}_{2}$ per cigarette and 6 to $9 \mu \mathrm{g}$ of active LPS per gram of a cigarette can be extracted. The amount of $\mathrm{H}_{2} \mathrm{O}_{2}$ used in this work appears less important (up to $200 \mathrm{nmol}$ in $200 \mu \mathrm{L}$ ), whereas the amount of LPS appears in the same range (up to $10 \mu \mathrm{g}$ in $100 \mu \mathrm{L})$.

In conclusion, we demonstrated the anticytotoxic, antioxidant, anti-inflammatory properties of the BUD:HP $\beta C D$ complex with protective activity against PI3K/Akt signaling activation and HDAC2 inhibition induced by oxidative stress. The antioxidant and anticytotoxic properties appeared essentially due to $\mathrm{HP} \beta C D$ while the anti-inflammatory properties appeared mainly to be due to BUD. Further investigations are clearly needed for a more complete view of the potential of the BUD:HP $\beta C D$ complex in other relevant models of oxidative stress-induced glucocorticoid insensitivity in vitro or in vivo.

\section{Material and Methods}

\subsection{Material}

A549 (ATCC ${ }^{\circledR}$ CCL185 ${ }^{\mathrm{TM}}$ ) and THP-1 (ATCC ${ }^{\circledR}$ TIB-202 ${ }^{\mathrm{TM}}$ ) cells were purchased from the American Type Culture Collection (Manassas, VA, USA). HP $\beta C D$ was obtained from Roquette, Lestrem, France. $\mathrm{H}_{2} \mathrm{O}_{2}$, Lipopolysaccharides (LPSs), Budesonide (BUD), Phorbol Myristate Acetate (PMA), M $\beta C D$, sphingomyelinase from Bacillus cereus, $N$-acetyl-L-cysteine (NAC), 2,2-Diphenyl-1-picrylhydrazyl (DPPH•), and L-ascorbic-acid (vitamin C) were ordered from Sigma-Aldrich (Saint Louis, MO, USA). A Cytotoxicity Detection KitPLUS (LDH) was ordered from Roche (Mannheim, Germany) and HOECHST ${ }^{\circledR}$ 33,342 staining solution from Life technologies (Eugene, OR, USA). LY294002 was ordered from Gibco (Camarillo, CA, USA). Phospho-Akt (Ser473) (D9E) $\mathrm{XP}^{\circledR}$ and Akt rabbit monoclonal antibodies were obtained from Cell Signaling Technology ${ }^{\circledR}$ (Beverly, MA, USA). $\beta$-actin (C4), mouse IgGk light chain binding protein (m-IgGk BP) conjugated to horseradish peroxidase (HRP) and mouse antirabbit IgG-HRP monoclonal antibodies were obtained from Santa Cruz Technology (Dallas, TX, USA). Horseradish Peroxidase (HRP) was ordered from Thermo Scientific ${ }^{\mathrm{TM}}$ (Rockford, IL, USA). Anti-HDAC2 (Ab-394) and Anti-phospho-HDAC2 (pSer394) antibodies produced in rabbit were ordered from Sigma-Aldrich (Saint Louis, MO, USA). Phenolsulfonphtalein (phenol red) was obtained from Merck (Darmstadt, Germany). A Human IL-8/CXCL8 DuoSet ELISA kit was obtained from R\&D systems (Minneapolis, MN, USA). Trimethylsilyl-3-propionide acid- $d 4$ (TMSP) and deuterium oxide $(99.96 \%$ D) were purchased from Eurisotop (Gif-sur-Yvette, France). Certified maleic acid and phosphate buffer powder were provided by Sigma-Aldrich (Karlsruhe, Germany). NMR measurements were recorded on a Bruker Avance spectrometer operating at $500.13 \mathrm{MHz}$ for the proton signal acquisition and equipped with a 5-mm TCI cryoprobe with a Z-gradient.

\subsection{BUD:HP $\beta C D$ Complex Stock Solution Preparation and Characterization}

We adapted the method of Dufour et al. [64]. The BUD:HP $\beta C D$ complex stock solutions were prepared by adding $200 \mathrm{mM} \mathrm{HP} \beta C D$ (molar substitution $=0.64$ ) in deionized water to BUD powder at a final concentration of $8.13 \mathrm{mM}$ (BUD:HP $\beta C D$ 1:25 molar ratio). The solution was then thoroughly mixed for $1 \mathrm{~h} 30 \mathrm{~min}$ (13,500 rpm) with a T25 basic Ultra-Turrax ${ }^{\circledR}$ homogenizer from IKA (Staufen, Germany) and filtered $(0.22-\mu \mathrm{m}$ filter unit). BUD and $\mathrm{HP} \beta C D$ were quantified in the solution obtained by HPLC-UV and ${ }^{1} \mathrm{H}-\mathrm{NMR}$, respectively, and checked for complexation as described by Dufour et al. [64]. Solutions were stored at $4{ }^{\circ} \mathrm{C}$ and renewed every 2 months. 


\subsection{Cell Handling}

A549 [40] and THP-1 [41] cells were grown in DMEM (1X) and RPMI-1640 medium (1X) (Gibco, Paisley, UK), respectively, and were both supplemented with FBS (10\%) and penicillin-streptomycin (1\%) (Gibco, Grand Island, NY, USA) at $37^{\circ} \mathrm{C}$ in a $5 \% \mathrm{CO}_{2}$ humidified atmosphere. Sub-cultures were performed according to the manufacturer's instructions. To activate THP-1 in macrophage-like cells (A-THP-1), cells were resuspended in fresh media, and phorbol 12-myristate 13-acetate (PMA) was added (final concentration $200 \mu \mathrm{g} / \mathrm{L}$ ) to the THP-1-containing medium [65]. A549 and THP-1 cells were then seeded in culture microplates, dishes or flasks depending on the experiment and incubated until sub-confluent (A549, 80\%) or $24 \mathrm{~h}$ (THP-1) at $37{ }^{\circ} \mathrm{C}$ in a $5 \% \mathrm{CO}_{2}$ humidified atmosphere. For experiments, test molecules were dissolved in 1\% FBS-supplemented medium, unless otherwise mentioned. When prior cell cholesterol or sphingomyelin depletion was required, cells were preincubated for $30 \mathrm{~min}$ with $5 \mathrm{mM}$ methyl- $\beta$-cyclodextrin $(\mathrm{M} \beta \mathrm{CD})$ or $50 \mathrm{mU} / \mathrm{mL}$ of sphingomyelinase from Bacillus cereus [66] in 1\% FBS-supplemented medium, respectively.

\subsection{Cytotoxicity Studies}

\subsubsection{Lactate Dehydrogenase Assay}

A549 cells in 96-well plates were incubated with increasing concentrations of BUD, HP $\beta C D$, or BUD:HP $\beta C D$ complex, or with $\mathrm{H}_{2} \mathrm{O}_{2}+$ LPS with/without increasing concentrations of BUD, $\mathrm{HP} \beta C D$, or BUD:HP $\beta C D$ complex. The activity of lactate dehydrogenase (LDH) released by non-viable cells in the supernatant was quantified using the Cytotoxicity Detection KitPLUS (LDH) from Roche (Mannheim, Germany) according to the manufacturer's instructions.

\subsubsection{HOECHST Nuclear Staining}

A549 cells in ibiTreat $\mu$-slides 2 wells from ibidi (Martinsried, Germany) were incubated with $\mathrm{H}_{2} \mathrm{O}_{2}+$ LPS with/without BUD, HP $\beta C D$, or BUD:HP $\beta C D$ complex. Cells were then washed with PBS, covered with a 2000-fold dilution of HOECHST ${ }^{\circledR} 33,342$ staining solution (Life technologies, Eugene, OR, USA) in PBS, and incubated $5 \mathrm{~min}$ at room temperature protected from light. Cells were then washed with PBS and imaged with a fluorescence microscope $\left(\lambda_{\mathrm{ex}} / \mathrm{em}=350 / 461\right.$, DAPI filter set). Cells with bright and/or fragmented nuclei were considered apoptotic. The proportion of apoptotic cells was calculated from a total cell count of 400/well. $\mathrm{H}_{2} \mathrm{O}_{2}+$ LPS concentrations were those preselected for LDH assay.

\subsection{DCF Assay for Determining ROS Generation}

We adapted the method of Wang and Joseph [67]. Briefly, A549 cells in 96-well plates were incubated for $30 \mathrm{~min}$ with 10 or $50 \mu \mathrm{M}$ membrane-permeant and non-fluorescent $2^{\prime}, 7^{\prime}$-dichlorofluorescein diacetate (DCFDA) (Sigma-Aldrich, Saint Louis, MO, USA), which was deacetylated by non-specific intracellular esterases into the membrane-impermeant and non-fluorescent $\mathrm{DCFH}_{2}$. Cells were then washed with Hank's balanced salt solution (HBSS) and incubated with $\mathrm{H}_{2} \mathrm{O}_{2}+$ LPS with/without BUD, HP $\beta C D$, or BUD:HP $\beta C D$ complex in HBSS. Oxidative stress was evaluated through the measure of the fluorescence of DCF resulting from the oxidation of $\mathrm{DCFH}_{2}$ by intracellular oxidants $\left(\lambda_{\mathrm{ex}}=490 \mathrm{~nm}\right.$; $\left.\lambda_{\mathrm{em}}=523 \mathrm{~nm}\right)$.

\subsection{Evaluation of Protein Quantity by Western Blotting}

A549 cells in 6-well plates or $60 \times 15 \mathrm{~mm}$ culture dishes were incubated with $\mathrm{H}_{2} \mathrm{O}_{2}+$ LPS with/without BUD, HP $\beta C D$, or BUD:HP $\beta C D$ complex. After incubation, cells were washed with ice-cold PBS and scraped off with a cold scraper in the presence of ice-cold RIPA or Biovision's cell lysis buffer supplemented with protease and phosphatase inhibitor cocktails. Detached cells in lysis buffer were then incubated for $30 \mathrm{~min}$ at $4{ }^{\circ} \mathrm{C}$ with agitation in a 2-mL microcentrifuge tube and 
centrifuged for $10 \mathrm{~min}\left(10,000 \times g, 4^{\circ} \mathrm{C}\right)$. The supernatant (whole-cell lysate) was stored at $-80^{\circ} \mathrm{C}$ at least overnight. A quantity of $30 \mu \mathrm{g}$ of proteins per sample was mixed with 1X NuPAGE LDS sample buffer and 1X NuPAGE sample reducing agent (Thermo Scientific ${ }^{\mathrm{TM}}$, Carlsbad, CA, USA) and heated for $10 \mathrm{~min}$ at $70^{\circ} \mathrm{C}$. Samples were then electrophoresed on precasted NuPAGE Bis-Tris gels in the presence of MOPS (3-(N-morpholino)propanesulfonic acid) running buffer 1X, transferred to PVDF (Polyvinylidene difluoride) transfer membranes (Thermo Scientific ${ }^{\mathrm{TM}}$, Rockford, IL, USA) in the presence of NuPAGE transfer buffer $1 X$ (Thermo Scientific ${ }^{\mathrm{TM}}$, Carlsbad, CA, USA) and blocked for $1 \mathrm{~h}$ in $5 \%$ non-fat dry milk in $20 \mathrm{~mL}$ of tris-buffered saline $1 \mathrm{X}$ containing $0.05 \%$ Tween 20 (TBS-T). Membranes were incubated overnight at $4{ }^{\circ} \mathrm{C}$ with primary antibodies with gentle agitation, washed 3 times with TBS-T, then incubated for $1 \mathrm{~h}$ at room temperature with the appropriated HRP-conjugated secondary antibodies. The manufacturer's recommendations were followed for antibody dilutions. After washing 3 times with TBS-T, blots were revealed using the SuperSignal West Pico Chemiluminescent Substrate (Thermo Scientific $^{\mathrm{TM}}$, Rockford, IL, USA), the Fusion Pulse 7 apparatus and Fusion Capt Advance Pulse 7 software. To reveal proteins with similar migration profiles, membranes were washed in TBS-T after the first reveal, and antibodies were stripped with a 10-min bath in Restore ${ }^{\mathrm{TM}}$ Western Blot Stripping Buffer (Thermo Scientific ${ }^{\mathrm{TM}}$, Rockford, IL, USA) and washed again with TBS-T. Then, the Western blot protocol was repeated from the block for $1 \mathrm{~h}$ in 5\% non-fat dry milk in $20 \mathrm{~mL}$ of TBS-T.

\subsection{Evaluation of Inflammatory Cytokine (IL-8) Expression by Sandwich ELISA}

A-THP-1 cells in 96-well plates were incubated with $\mathrm{H}_{2} \mathrm{O}_{2}+$ LPS with/without BUD, HP $\beta C D$, or BUD:HP $\beta C D$ complex. A 4-fold dilution of the supernatant in RPMI-1640 medium was stored overnight at $-80{ }^{\circ} \mathrm{C}$. IL-8 cytokine levels in diluted supernatant were quantified using the Human IL-8/CXCL8 DuoSet ELISA kit (R\&D systems, Minneapolis, MN, USA) according to the manufacturer's instructions.

\subsection{Data Analysis}

GraphPad Prism ${ }^{\circledR}$ (version 4.03 for Windows, GraphPad Prism Software, San Diego, CA, USA) was used for graphic illustrations and statistical analysis. The statistical tests used to study the significance of the results are described in the captions of the corresponding figures.

Supplementary Materials: The following are available online. Figure S1: Cholesterol content in A549 cells untreated (control), incubated with methyl- $\beta$-cyclodextrin $(M \beta C D)$ for $30 \mathrm{~min}$, and incubated with methyl- $\beta$-cyclodextrin $(M \beta C D)$ for $30 \mathrm{~min}$ and thereafter in medium for $2 \mathrm{~h}$. Figure S2: Effect of the BUD: HP $\beta C D$ complex (green) and HP $\beta C D$ (blue) on oxidant generation induced by $\mathrm{H}_{2} \mathrm{O}_{2}+$ LPS after treatment for $2 \mathrm{~h}$ in non-depleted and sphingomyelin-depleted A549 cells. Figure S3: Effect of the BUD:HP $\beta C D$ complex versus $\mathrm{HP} \beta C D$ on $\mathrm{H}_{2} \mathrm{O}_{2}(\mathbf{A})$ and 2,2-Diphenyl-1-picrylhydrazyl (DPPH•) (B) after $25 \mathrm{~min}(\mathbf{A})$ and $1 \mathrm{~h}$ of incubation (B). Figure S4: Cholesterol content in A549 cells incubated with the BUD:HP $\beta C D$ complex, HP $\beta C D$ or BUD for $2 \mathrm{~h}$. Figure S5: HP $\beta C D$ relative quantity in A549 extracellular medium after $2 \mathrm{~h}$ of incubation with the BUD:HP $\beta C D$ complex (green bars) and HP $\beta C D$ (blue bars). HP $\beta C D$ was quantified using proton nuclear magnetic resonance spectroscopy. Figure S6: Oxidant generation kinetic in A549 cells after treatment with $\mathrm{H}_{2} \mathrm{O}_{2}$ + LPS $(1 \mathrm{mM}+100 \mu \mathrm{g} / \mathrm{mL})$ for $6 \mathrm{~h}$ and effect of $N$-acetyl-L-cysteine (NAC) and Vit $\mathrm{C}$ on $\mathrm{H}_{2} \mathrm{O}_{2}+$ LPS-induced oxidant generation. Figure S7: Akt phosphorylation induced by $\mathrm{H}_{2} \mathrm{O}_{2}+\mathrm{LPS}, \mathrm{H}_{2} \mathrm{O}_{2}$ and LPS in A549 cells after 2 $\mathrm{h}$ of incubation. Figure S8: Percentage of IL-8 released after A 549 cells pretreatment for 30 min with trichostatin (TSA) and incubation for $2 \mathrm{~h}$ with TNF- $\alpha$ in presence of BUD + HP $\beta C D$ complex, BUD or HP $\beta C D$ [68-71].

Author Contributions: Conceptualization, D.C., J.C.B. and M.-P.M.-L.; Methodology, J.C.B.; P.D.T.; B.E. and M.-P.M.-L. Investigation, J.C.B.; P.D.T.; B.E.; Resources, P.D.T.; B.E. and M.-P.M.-L.; Writing-Original Draft Preparation, J.C.B.; Writing-Review and Editing, J.C.B. and M.-P.M.-L.; Supervision, M.-P.M.-L.; Project Administration, D.C. and M.-P.M.-L.; Funding Acquisition, D.C., B.E. and M.-P.M.-L. All authors have read and agreed to the published version of the manuscript.

Funding: This research received no external funding.

Acknowledgments: JCB thanks WB and OJ for the BUD:HP $\beta C D$ complex used in this study and V. Mohymont who provided dedicated technical assistance. This work was supported by Walloon Region (AEROGAL) and FRIA.

Conflicts of Interest: The authors declare no conflict of interest. 


\section{References}

1. Cazzola, M.; Rogliani, P.; Stolz, D.; Matera, M.G. Pharmacological treatment and current controversies in COPD. F1000Research 2019, 8. [CrossRef] [PubMed]

2. Nici, L.; Mammen, M.J.; Charbek, E.; Alexander, P.E.; Au, D.H.; Boyd, C.M.; Criner, G.J.; Donaldson, G.C.; Dreher, M.; Fan, V.S.; et al. Pharmacologic Management of Chronic Obstructive Pulmonary Disease. An Official American Thoracic Society Clinical Practice Guideline. Am. J. Respir. Crit Care Med. 2020, 201, e56-e69. [CrossRef] [PubMed]

3. Marwick, J.A.; Adcock, I.M.; Chung, K.F. Overcoming reduced glucocorticoid sensitivity in airway disease: Molecular mechanisms and therapeutic approaches. Drugs 2010, 70, 929-948. [CrossRef] [PubMed]

4. Barnes, P.J. Corticosteroid resistance in patients with asthma and chronic obstructive pulmonary disease. J. Allergy Clin. Immunol. 2013, 131, 636-645. [CrossRef] [PubMed]

5. Barnes, P.J. Inflammatory mechanisms in patients with chronic obstructive pulmonary disease. J. Allergy Clin. Immunol. 2016, 138, 16-27. [CrossRef] [PubMed]

6. Barnes, P.J. Glucocorticosteroids. Handb. Exp. Pharmacol. 2017, 237, 93-115.

7. Mei, D.; Tan, W.S.D.; Wong, W.S.F. Pharmacological strategies to regain steroid sensitivity in severe asthma and COPD. Curr. Opin. Pharmacol. 2019, 46, 73-81. [CrossRef]

8. Bi, J.; Min, Z.; Yuan, H.; Jiang, Z.; Mao, R.; Zhu, T.; Liu, C.; Zeng, Y.; Song, J.; Du, C.; et al. PI3K inhibitor treatment ameliorates the glucocorticoid insensitivity of PBMCs in severe asthma. Clin. Transl. Med. 2020, 9, 22. [CrossRef]

9. Pelaia, G.; Vatrella, A.; Busceti, M.T.; Fabiano, F.; Terracciano, R.; Matera, M.G.; Maselli, R. Molecular and cellular mechanisms underlying the therapeutic effects of budesonide in asthma. Pulm. Pharmacol. Ther. 2016, 40, 15-21. [CrossRef]

10. Tashkin, D.P.; Lipworth, B.; Brattsand, R. Benefit: Risk Profile of Budesonide in Obstructive Airways Disease. Drugs 2019, 79, 1757-1775. [CrossRef]

11. Janson, C. Treatment with inhaled corticosteroids in chronic obstructive pulmonary disease. J. Thorac. Dis. 2020, 12, 1561-1569. [CrossRef]

12. Dufour, G.; Bigazzi, W.; Wong, N.; Boschini, F.; de Tullio, P.; Piel, G.; Cataldo, D.; Evrard, B. Interest of cyclodextrins in spray-dried microparticles formulation for sustained pulmonary delivery of budesonide. Int. J. Pharm. 2015, 495, 869-878. [CrossRef] [PubMed]

13. Loftsson, T.; Saokham, P.; Sa Couto, A.R. Self-association of cyclodextrins and cyclodextrin complexes in aqueous solutions. Int. J. Pharm. 2019, 560, 228-234. [CrossRef] [PubMed]

14. Jansook, P.; Ogawa, N.; Loftsson, T. Cyclodextrins: Structure, physicochemical properties and pharmaceutical applications. Int. J. Pharm. 2018, 535, 272-284. [CrossRef] [PubMed]

15. Crini, G. Review: A history of cyclodextrins. Chem. Rev. 2014, 114, 10940-10975. [CrossRef]

16. Braga, S.S. Cyclodextrins: Emerging Medicines of the New Millennium. Biomolecules 2019, 9, 801. [CrossRef] [PubMed]

17. Zidovetzki, R.; Levitan, I. Use of cyclodextrins to manipulate plasma membrane cholesterol content: Evidence, misconceptions and control strategies. Biochim. Biophys. Acta 2007, 1768, 1311-1324. [CrossRef]

18. di Cagno, M.P. The Potential of Cyclodextrins as Novel Active Pharmaceutical Ingredients: A Short Overview. Molecules 2016, 22, 1. [CrossRef]

19. Gould, S.; Scott, R.C. 2-Hydroxypropyl-beta-cyclodextrin (HP-beta-CD): A toxicology review. Food Chem. Toxicol. 2005, 43, 1451-1459. [CrossRef]

20. Malanga, M.; Szeman, J.; Fenyvesi, E.; Puskas, I.; Csabai, K.; Gyemant, G.; Fenyvesi, F.; Szente, L. “Back to the Future": A New Look at Hydroxypropyl Beta-Cyclodextrins. J. Pharm. Sci. 2016, 105, 2921-2931. [CrossRef]

21. Barnes, P.J. Role of HDAC2 in the pathophysiology of COPD. Annu. Rev. Physiol. 2009, 71, 451-464. [CrossRef] [PubMed]

22. Ito, K.; Ito, M.; Elliott, W.M.; Cosio, B.; Caramori, G.; Kon, O.M.; Barczyk, A.; Hayashi, S.; Adcock, I.M.; Hogg, J.C.; et al. Decreased histone deacetylase activity in chronic obstructive pulmonary disease. N. Engl. J. Med. 2005, 352, 1967-1976. [CrossRef] [PubMed]

23. Lasserre, R.; Guo, X.J.; Conchonaud, F.; Hamon, Y.; Hawchar, O.; Bernard, A.M.; Soudja, S.M.; Lenne, P.F.; Rigneault, H.; Olive, D.; et al. Raft nanodomains contribute to Akt/PKB plasma membrane recruitment and activation. Nat. Chem. Biol. 2008, 4, 538-547. [CrossRef] [PubMed] 
24. Calay, D.; Vind-Kezunovic, D.; Frankart, A.; Lambert, S.; Poumay, Y.; Gniadecki, R. Inhibition of Akt signaling by exclusion from lipid rafts in normal and transformed epidermal keratinocytes. J. Investig. Dermatol. 2010, 130, 1136-1145. [CrossRef]

25. Mollinedo, F.; Gajate, C. Lipid rafts as major platforms for signaling regulation in cancer. Adv. Biol. Regul. 2015, 57, 130-146. [CrossRef] [PubMed]

26. Gao, X.; Zhang, J. Spatiotemporal analysis of differential Akt regulation in plasma membrane microdomains. Mol. Biol. Cell. 2008, 19, 4366-4373. [CrossRef] [PubMed]

27. Dos Santos, A.G.; Bayiha, J.C.; Dufour, G.; Cataldo, D.; Evrard, B.; Silva, L.C.; Deleu, M.; Mingeot-Leclercq, M.P. Changes in membrane biophysical properties induced by the Budesonide/Hydroxypropyl-beta-cyclodextrin complex. Biochim. Biophys. Acta Biomembr. 2017, 1859, 1930-1940. [CrossRef]

28. Nakayama, T.; Church, D.F.; Pryor, W.A. Quantitative analysis of the hydrogen peroxide formed in aqueous cigarette tar extracts. Free Radic. Biol. Med. 1989, 7, 9-15. [CrossRef]

29. Yamaguchi, Y.; Kagota, S.; Haginaka, J.; Kunitomo, M. Peroxynitrite-generating species: Good candidate oxidants in aqueous extracts of cigarette smoke. Jpn. J. Pharmacol. 2000, 82, 78-81. [CrossRef]

30. Valenca, S.S.; Silva, B.F.; Lopes, A.A.; Romana-Souza, B.; Marinho Cavalcante, M.C.; Lima, A.B.; Goncalves Koatz, V.L.; Porto, L.C. Oxidative stress in mouse plasma and lungs induced by cigarette smoke and lipopolysaccharide. Environ. Res. 2008, 108, 199-204. [CrossRef]

31. Tuder, R.M.; Petrache, I. Pathogenesis of chronic obstructive pulmonary disease. J. Clin. Investig. 2012, 122, 2749-2755. [CrossRef] [PubMed]

32. Wiegman, C.H.; Michaeloudes, C.; Haji, G.; Narang, P.; Clarke, C.J.; Russell, K.E.; Bao, W.; Pavlidis, S.; Barnes, P.J.; Kanerva, J.; et al. Oxidative stress-induced mitochondrial dysfunction drives inflammation and airway smooth muscle remodeling in patients with chronic obstructive pulmonary disease. J. Allergy Clin. Immunol. 2015, 136, 769-780. [CrossRef] [PubMed]

33. Marwick, J.A.; Caramori, G.; Stevenson, C.S.; Casolari, P.; Jazrawi, E.; Barnes, P.J.; Ito, K.; Adcock, I.M.; Kirkham, P.A.; Papi, A. Inhibition of PI3Kdelta restores glucocorticoid function in smoking-induced airway inflammation in mice. Am. J. Respir. Crit Care Med. 2009, 179, 542-548. [CrossRef]

34. To, Y.; Ito, K.; Kizawa, Y.; Failla, M.; Ito, M.; Kusama, T.; Elliott, W.M.; Hogg, J.C.; Adcock, I.M.; Barnes, P.J. Targeting phosphoinositide-3-kinase-delta with theophylline reverses corticosteroid insensitivity in chronic obstructive pulmonary disease. Am. J. Respir. Crit Care Med. 2010, 182, 897-904. [CrossRef]

35. Hammoud, Z.; Khreich, N.; Auezova, L.; Fourmentin, S.; Elaissari, A.; Greige-Gerges, H. Cyclodextrin-membrane interaction in drug delivery and membrane structure maintenance. Int. J. Pharm. 2019, 564, 59-76. [CrossRef] [PubMed]

36. Lopez-Revuelta, A.; Sanchez-Gallego, J.I.; Hernandez-Hernandez, A.; Sanchez-Yague, J.; Llanillo, M. Membrane cholesterol contents influence the protective effects of quercetin and rutin in erythrocytes damaged by oxidative stress. Chem. Biol. Interact. 2006, 161, 79-91. [CrossRef] [PubMed]

37. Zhang, Y.; Chen, F.; Chen, J.; Huang, S.; Chen, J.; Huang, J.; Li, N.; Sun, S.; Chu, X.; Zha, L. Soyasaponin Bb inhibits the recruitment of toll-like receptor 4 (TLR4) into lipid rafts and its signaling pathway by suppressing the nicotinamide adenine dinucleotide phosphate (NADPH) oxidase-dependent generation of reactive oxygen species. Mol. Nutr. Food Res. 2016, 60, 1532-1543. [CrossRef]

38. Wu, J.; Liu, C.; Zhang, L.; Qu, C.H.; Sui, X.L.; Zhu, H.; Huang, L.; Xu, Y.F.; Han, Y.L.; Qin, C. Histone deacetylase-2 is involved in stress-induced cognitive impairment via histone deacetylation and PI3K/AKT signaling pathway modification. Mol. Med. Rep. 2017, 16, 1846-1854. [CrossRef] [PubMed]

39. Sun, X.J.; Li, Z.H.; Zhang, Y.; Zhong, X.N.; He, Z.Y.; Zhou, J.H.; Chen, S.N.; Feng, Y. Theophylline and dexamethasone in combination reduce inflammation and prevent the decrease in HDAC2 expression seen in monocytes exposed to cigarette smoke extract. Exp. Ther. Med. 2020, 19, 3425-3431. [CrossRef]

40. Schulz, C.; Farkas, L.; Wolf, K.; Kratzel, K.; Eissner, G.; Pfeifer, M. Differences in LPS-induced activation of bronchial epithelial cells (BEAS-2B) and type II-like pneumocytes (A-549). Scand. J. Immunol. 2002, 56, 294-302. [CrossRef]

41. Bosshart, H.; Heinzelmann, M. THP-1 cells as a model for human monocytes. Ann. Transl. Med. 2016, 4, 438. [CrossRef]

42. Ito, K.; Yamamura, S.; Essilfie-Quaye, S.; Cosio, B.; Ito, M.; Barnes, P.J.; Adcock, I.M. Histone deacetylase 2-mediated deacetylation of the glucocorticoid receptor enables NF-kappaB suppression. J. Exp. Med. 2006, 203, 7-13. [CrossRef] 
43. Piao, J.; Chen, L.; Quan, T.; Li, L.; Quan, C.; Piao, Y.; Jin, T.; Lin, Z. Superior efficacy of co-treatment with the dual PI3K/mTOR inhibitor BEZ235 and histone deacetylase inhibitor Trichostatin A against NSCLC. Oncotarget 2016, 7, 60169-60180. [CrossRef] [PubMed]

44. Yamaguchi, M.S.; McCartney, M.M.; Falcon, A.K.; Linderholm, A.L.; Ebeler, S.E.; Kenyon, N.J.; Harper, R.H.; Schivo, M.; Davis, C.E. Modeling cellular metabolomic effects of oxidative stress impacts from hydrogen peroxide and cigarette smoke on human lung epithelial cells. J. Breath Res. 2019, 13, 036014. [CrossRef]

45. Hasday, J.D.; Bascom, R.; Costa, J.J.; Fitzgerald, T.; Dubin, W. Bacterial endotoxin is an active component of cigarette smoke. Chest 1999, 115, 829-835. [CrossRef]

46. Volobuef, C.; Moraes, C.M.; Nunes, L.A.; Cereda, C.M.; Yokaichiya, F.; Franco, M.K.; Braga, A.F.; De, P.E.; Tofoli, G.R.; Fraceto, L.F.; et al. Sufentanil-2-hydroxypropyl-beta-cyclodextrin inclusion complex for pain treatment: Physicochemical, cytotoxicity, and pharmacological evaluation. J. Pharm. Sci. 2012, 101, 3698-3707. [CrossRef]

47. Lachowicz, M.; Stanczak, A.; Kolodziejczyk, M. Characteristic of Cyclodextrins: Their role and use in the pharmaceutical technology. Curr. Drug Targets 2020. [CrossRef] [PubMed]

48. Anraku, M.; Iohara, D.; Wada, K.; Taguchi, K.; Maruyama, T.; Otagiri, M.; Uekama, K.; Hirayama, F. Antioxidant and renoprotective activity of 2-hydroxypropyl-beta-cyclodextrin in nephrectomized rats. J. Pharm. Pharmacol. 2016, 68, 608-614. [CrossRef] [PubMed]

49. Zimmer, S.; Grebe, A.; Bakke, S.S.; Bode, N.; Halvorsen, B.; Ulas, T.; Skjelland, M.; De, N.D.; Labzin, L.I.; Kerksiek, A.; et al. Cyclodextrin promotes atherosclerosis regression via macrophage reprogramming. Sci. Transl. Med. 2016, 8, 333ra50. [CrossRef]

50. Lopez-Nicolas, J.M.; Rodriguez-Bonilla, P.; Garcia-Carmona, F. Cyclodextrins and antioxidants. Crit Rev. Food Sci. Nutr. 2014, 54, 251-276. [CrossRef]

51. Gross, N.J.; Barnes, P.J. New Therapies for Asthma and Chronic Obstructive Pulmonary Disease. Am. J. Respir. Crit Care Med. 2017, 195, 159-166. [CrossRef] [PubMed]

52. Lopez, C.A.; de Vries, A.H.; Marrink, S.J. Computational microscopy of cyclodextrin mediated cholesterol extraction from lipid model membranes. Sci. Rep. 2013, 3, 2071. [CrossRef] [PubMed]

53. Ueda, K.; Nishimoto, Y.; Kimura, G.; Masuko, T.; Barnes, P.J.; Ito, K.; Kizawa, Y. Repeated lipopolysaccharide exposure causes corticosteroid insensitive airway inflammation via activation of phosphoinositide-3-kinase delta pathway. Biochem. Biophys. Rep. 2016, 7, 367-373. [PubMed]

54. Zheng, X.; Zhang, W.; Hu, X. Different concentrations of lipopolysaccharide regulate barrier function through the PI3K/Akt signalling pathway in human pulmonary microvascular endothelial cells. Sci. Rep. 2018, 8, 9963. [CrossRef]

55. Aldini, G.; Altomare, A.; Baron, G.; Vistoli, G.; Carini, M.; Borsani, L.; Sergio, F. N-Acetylcysteine as an antioxidant and disulphide breaking agent: The reasons why. Free Radic. Res. 2018, 52, 751-762. [CrossRef]

56. George, S.M.; Gaylor, J.D.; Leadbitter, J.; Grant, M.H. The effect of betacyclodextrin and hydroxypropyl betacyclodextrin incorporation into plasticized poly(vinyl chloride) on its compatibility with human U937 cells. J. Biomed. Mater. Res. B Appl. Biomater. 2011, 96, 310-315. [CrossRef]

57. Matassoli, F.L.; Leao, I.C.; Bezerra, B.B.; Pollard, R.B.; Lutjohann, D.; Hildreth, J.E.K.; Arruda, L.B. Hydroxypropyl-Beta-Cyclodextrin Reduces Inflammatory Signaling from Monocytes: Possible Implications for Suppression of HIV Chronic Immune Activation. mSphere 2018, 3. [CrossRef] [PubMed]

58. Onishi, M.; Ozasa, K.; Kobiyama, K.; Ohata, K.; Kitano, M.; Taniguchi, K.; Homma, T.; Kobayashi, M.; Sato, A.; Katakai, Y.; et al. Hydroxypropyl-beta-cyclodextrin spikes local inflammation that induces Th2 cell and T follicular helper cell responses to the coadministered antigen. J. Immunol. 2015, 194, 2673-2682. [CrossRef] [PubMed]

59. Higham, A.; Karur, P.; Jackson, N.; Cunoosamy, D.M.; Jansson, P.; Singh, D. Differential anti-inflammatory effects of budesonide and a p38 MAPK inhibitor AZD7624 on COPD pulmonary cells. Int. J. Chronic Obstruct. Pulmon. Dis. 2018, 13, 1279-1288. [CrossRef] [PubMed]

60. Stella, V.J.; Rao, V.M.; Zannou, E.A.; Zia, V. Mechanisms of drug release from cyclodextrin complexes. Adv. Drug Deliv. Rev. 1999, 36, 3-16. [CrossRef]

61. Dahlstrom, K.; Thorsson, L.; Larsson, P.; Nikander, K. Systemic availability and lung deposition of budesonide via three different nebulizers in adults. Ann. Allergy Asthma Immunol. 2003, 90, 226-232. [CrossRef]

62. Thorsson, L.; Edsbacker, S.; Conradson, T.B. Lung deposition of budesonide from Turbuhaler is twice that from a pressurized metered-dose inhaler P-MDI. Eur. Respir. J. 1994, 7, 1839-1844. [CrossRef] [PubMed] 
63. Fernandes, C.A.; Vanbever, R. Preclinical models for pulmonary drug delivery. Expert Opin. Drug Deliv. 2009, 6, 1231-1245. [CrossRef] [PubMed]

64. Dufour, G.; Evrard, B.; de Tullio, P. 2D-Cosy NMR Spectroscopy as a Quantitative Tool in Biological Matrix: Application to Cyclodextrins. AAPS J. 2015, 17, 1501-1510. [CrossRef]

65. Lemaire, S.; Mingeot-Leclercq, M.P.; Tulkens, P.M.; Van Bambeke, F. Study of macrophage functions in murine J774 cells and human activated THP-1 cells exposed to oritavancin, a lipoglycopeptide with high cellular accumulation. Antimicrob. Agents Chemother. 2014, 58, 2059-2066. [CrossRef]

66. Verstraeten, S.L.; Albert, M.; Paquot, A.; Muccioli, G.G.; Tyteca, D.; Mingeot-Leclercq, M.P. Membrane cholesterol delays cellular apoptosis induced by ginsenoside Rh2, a steroid saponin. Toxicol. Appl. Pharmacol. 2018, 352, 59-67. [CrossRef]

67. Wang, H.; Joseph, J.A. Quantifying cellular oxidative stress by dichlorofluorescein assay using microplate reader. Free Radic. Biol. Med. 1999, 27, 612-616. [CrossRef]

68. Pick, E.; Keisari, Y. A simple colorimetric method for the measurement of hydrogen peroxide produced by cells in culture. J. Immunol. Methods 1980, 38, 161-170. [CrossRef]

69. Bahorun, T.; Gressier, B.; Trotin, F.; Brunet, C.; Dine, T.; Luyckx, M.; Vasseur, J.; Cazin, M.; Cazin, J.C.; Pinkas, M. Oxygen species scavenging activity of phenolic extracts from hawthorn fresh plant organs and pharmaceutical preparations. Arzneimittelforschung 1996, 46, 1086-1089.

70. Brand-Williams, W.; Cuvelier, M.E.; Berset, C. Use of a free radical method to evaluate antioxidant activity. LWT-Food Sci. Technol. 1995, 28, 25-30. [CrossRef]

71. Matheus, N.; Hansen, S.; Rozet, E.; Peixoto, P.; Maquoi, E.; Lambert, V.; Noel, A.; Frederich, M.; Mottet, D.; de Tullio, P. An easy, convenient cell and tissue extraction protocol for nuclear magnetic resonance metabolomics. Phytochem. Anal. 2014, 25, 342-349. [CrossRef] [PubMed]

Sample Availability: Samples of the compounds are available from the authors. The complex has to be prepared each three months for sake of stability.

Publisher's Note: MDPI stays neutral with regard to jurisdictional claims in published maps and institutional affiliations.

(C) 2020 by the authors. Licensee MDPI, Basel, Switzerland. This article is an open access article distributed under the terms and conditions of the Creative Commons Attribution (CC BY) license (http://creativecommons.org/licenses/by/4.0/). 